\title{
Healthy eCONOMICS OR CAUTIONARY TALES? The NARRATIVE MICROECONOMICS OF FOUR MATTHEAN HEALING STORIES
}

\author{
Author: \\ Laura Anderson ${ }^{1,2}$ \\ Affiliations: \\ ${ }^{1}$ Graduate Theological \\ Union, Berkeley, USA \\ ${ }^{2}$ Department of New \\ Testament Studies, Faculty \\ of Theology, University of \\ Pretoria, South Africa \\ Correspondence to: \\ Laura Anderson \\ e-mail: \\ landerson@ses.gtu.edu \\ Postal address: \\ Graduate Theological \\ Union; Box 55; 2400 Ridge \\ Road; Berkeley, CA 94709- \\ 1212 USA

\section{Keywords:} \\ Gospel of Matthew; \\ healing narratives; \\ narrative microeconomic \\ analysis; globalisation; \\ supplication \\ Dates: \\ Accepted: 03 July 2009 \\ Received: 06 July 2009 \\ Published: 11 Nov. 2009 \\ How to cite this article: \\ Anderson, L., 2009, \\ 'Healthy economics or \\ cautionary tales? \\ The narrative \\ microeconomics of four \\ Matthean healing stories', \\ HTS Teologiese/Theological \\ Studies 65(1), Art. \#320, 16 \\ pages. DOI: $10.4102 /$ hts. \\ v65i1.320
}

This article is available

at:

http://www.hts.org.za

Note:

Laura Anderson is a $\mathrm{PhD}$

student at the Graduate

Theological Union,

Berkeley, CA.

She participates in

the research project

'Biblical Theology and

Hermeneutics', directed

by Prof. Dr Andries G.

van Aarde, Honorary

Professor of the Faculty of

Theology at the

University of Pretoria.

(C) 2009. The Authors. Licensee: OpenJournals

Publishing. This work

is licensed under the

Creative Commons

Attribution License.

\section{ABSTRACT}

This article explores the four Matthean stories wherein an individual supplicant requests a healing on behalf of someone else: the centurion for his paralyzed servant, the ruler for his dead daughter, the Canaanite woman for her demon-possessed daughter, and the man for his epileptic son. The paper proposes a methodology of narrative microeconomic analysis. By applying the method to the stories, a pattern of three primary exchanges is observed: the locational, healing and conflict exchanges. By examining how the stories conform to and deviate from this pattern, a complex picture of the textual microeconomies emerges, one that contradicts the unitary macro-narrative of healing. The microeconomic analysis reveals Jesus to be a complex, ambivalent figure: He creates conflicts that hinder the healing process and invariably excludes someone or some group before completing any healing. The pedagogical, formational and theological implications of these complexities are briefly considered in local and global contexts.

\section{INTRODUCTION}

From a macro-narrative perspective, the dynamics of Jesus' healing economy, as presented in the Gospel of Matthew, would seem to be robustly sound: Desired healings are uniformly accomplished by Jesus. But what about the microeconomies, the narratively distinct exchanges, of these healing stories? Are they as singularly hale and healthy as the overarching textual economy would suggest? To begin exploring this question, this paper examines the four Matthean healing stories in which an individual supplicant requests a healing on behalf of another person. The present work employs a methodology of narrative microeconomic analysis. This method is a modified synchronic formal criticism operationalised not in terms of literary forms and genres but rather in terms of each story's microeconomic exchanges: Who gives what to whom and in return for what as the healing story unfolds? After a close reading of these textual exchanges, I suggest that each of these four stories enacts a similar literary pattern based on three primary exchanges: the locational, healing and conflict exchanges. However, this general pattern is differently enacted in each story. This variability is examined in detail, and each account's unique microeconomy is described. The textual exploration of the four narratives' general pattern of exchange as well as each one's unique iteration of the pattern reveals complexity and variation in each account's microeconomic dynamics as well as in its portrayal of Jesus. One characteristic common to each story's microeconomy is the role of Jesus as an initiator of conflict during the healing exchange. Another consistent story trait is that the conflict begun by Jesus develops along a continuum of inclusion and exclusion. By implication then, the uniform healing outcome of these stories depends, in part, on Jesus excluding someone. This textual disjuncture between the Matthean macro-narrative of Jesus' inclusive healing economy - all are healed - and the Matthean micro-narratives of Jesus' exclusionary healing economy - someone is always left out - is considered for its potential methodological, pedagogical, formational and theological implications for some western Christians who name themselves as inclusive progressives and who are seeking to construct more sustainable and more localised theological economies.

These issues are all addressed in this paper, the structure of which is as follows. Firstly, the specific and limited social contexts out of which and towards which this work is written will be given. Secondly, the methodology will be introduced and defined. Thirdly, the methodology will be applied sequentially to each of the four stories. Finally, the usefulness of the method will be assessed, and the implications of the textual explorations will be considered in light of the explicitly named social contexts, to which I now turn.

\section{MOTIVATING SOCIAL CONTEXTS}

This article has its provenance in real-world contexts whose locations and normative assumptions ought, for ethical and practical reasons, to be named briefly. The first and most obvious context is that of the Society of Biblical Literature Matthew section in which this work was originally presented, a gathering where all participants endeavoured to interpret aspects of the Gospel of Matthew from the standpoint of our real-world global contexts. In my case, my own motivating social contexts are quite local and very specific. They are the seminary classrooms where I am an instructor, and the gathering spaces of the mainline denominational church in which I teach adult Christian-formation classes, and which I call my spiritual home. Thus, from the beginning I wish to be very clear that I do not perceive the methodology proposed below to be either globally applicable or universally helpful. Rather, it represents an incomplete reflection on some of the theological dynamics operating within these specific locales.

Within my local academy, I teach New Testament and exegesis to MDiv students and to lay leaders. Even among the many students who critique the Bible for what they perceive as its patriarchalism, sexism, heterosexism, violence and injustice, I have noticed an unwillingness to turn a similarly critical lens to Jesus as he is literarily presented within the gospel texts. Students strongly resist reading Jesus as anyone or anything other than 'radically' good. While many of these students recognise that Jesus 
the literary character, Jesus the historical figure, and Jesus the Christ of later church doctrine are not necessarily co-extensive, there seems to remain an unvoiced worry that to view the Jesus of the gospels critically, to read this figure as other than perfectly inclusive and radically loving, is to undermine the whole of biblical reliability and authority. As a person, I have no appetite for gratuitous attacks on any individual's faith However, as an instructor, I do wonder how I can help students read through their resistance and thereby arrive at a more nuanced interpretation of Jesus as a literary figure, a reading that grapples more inclusively with his textual complexities.

Within my local church, we call ourselves a progressive and inclusive community; indeed, these qualities are among the institution's explicit core values. As a congregation, we also endeavour to take the Bible seriously and to live out the teachings of Jesus in responsive ways that are ecologically, economically and theologically sustainable. However, many of us wonder how to be a responsible Christian without reenacting the Church's sometimes triumphalist history, where the words of the Bible and of Jesus have been used to justify not so much progressive inclusion as oppressive exclusion, domination and violence. As a member of this community who teaches adult formation, I wonder if learning to read more attentively both the horror and the hope of biblical texts through the lenses of our modern local and global contexts might be one way to reckon with the Bible's and Christianity's complex histories, even as it provides us with insights for embodying more fully our values of inclusion, mutuality and Christian love.

These real-world contexts have strongly shaped the work that follows. With an eye on these contexts, I intend to propose a method of critical reading that might help students and parishioners alike become more objective readers of the Jesus who is presented in the gospels. Within the context of the Matthew forum, I suggest that such a critical reading strategy might have helpful, localising implications for some western Christians beyond my own immediate contexts who, recognising the complex interactions between enduring doctrinal ideas of Christ triumphant and the ongoing legacy of western imperialism around the world, hope to play a small part in creating different global realities. My aims are simply to offer a reading strategy that may help us wrestle more fully with the ways the biblical texts enact Jesus and to highlight one or two ways in which such a critical engagement might impact how we re-enact Jesus, for better and for worse, within local and global settings.

\section{OVERVIEW OF THE METHOD AND THE EXEGETICAL PROCESS}

In order to explore one way of reading the Jesus character critically, this paper will focus on the four Matthean healing stories where an individual supplicant requests a healing on behalf of another person. (This 'supplicant on behalf of another' will hereafter be abbreviated as SOBA, and the story in which this character type appears will be identified as a SOBA account). These four accounts - of the centurion and his servant, the leader and his daughter, the Canaanite woman and her daughter, and the man and his son - are chosen because they demonstrate a similar internal structure, which provides a type of control-of-variable strategy against which variations between the texts can be explored. These rather lengthy stories also include dialogue, narration, multiple characters and shifting geographies, which together afford us multiple locations for textual analysis.

This article owes a scholarly debt to form criticism's emphasis on miracle healing stories as a primarily literary phenomenon that nonetheless emerges from real-world social situations beyond the text (Theissen 1983:1, 2). Though the present work enacts form-critical assumptions in very different and less detailed ways, echoes of some form critics' three-section division of miracle healing stories (e.g., Betz 1978:72; Funk 1978:61) and their careful delineation of literary motifs (e.g., Theissen 1983: 47-72) can be heard reverberating herein. However, while each of the four stories considered below will be examined using a modified synchronic formal analysis, the desired outcome is neither a more nuanced literary taxonomy nor a supersentential narrative grammar (Funk 1978:59). Instead, this work seeks to operationalise the text's literary elements through the language of economics and the structural dynamics of exchange.

Economics herein is broadly understood as an examination of human behaviour and relationship in the allocation of limited resources that could potentially be distributed in any number of different ways (Kohler 1992:43; Mai 1964:8; Reynolds 1979:3). In particular, a focus on how scarce resources are allocated is the realm of microeconomics, in which the economic behaviour of individuals and small groups, such as households, is analysed (Kohler 1992:48; Makin 1975:6). This article accepts exchange as the basic dynamic of economics and therefore as the basic unit of narrative analysis. Exchange is defined herein as the cooperative action(s) undertaken by individuals to achieve individual objectives (Jackson 1996:2). Exchange assumes voluntary reciprocity, with both parties giving and receiving. As such, it is distinct from gift, which does not involve reciprocity, and from coercion, which nullifies voluntary participation (Jackson 1996:2).

While some basic notions of economics inform the process of this paper, it is important to note that this work is by no means proposing an analysis of reconstructed economic variables derived either from the texts themselves or from the late firstcentury milieu from which the texts are assumed to have emerged. Stated more plainly, this is not a microeconomic analysis in the modern, social-scientific sense. Instead, the proposed methodology borrows from economics a focus on exchange as a means of measuring economic behaviour, and from microeconomics a focus on individual, rather than aggregate, behaviour in the pursuit and allocation of scarce resources. These general ideas are removed from the boardroom of pie charts and bar graphs, and are adapted instead to the literary stage on which our texts appear. As such, this methodology is proposing an analysis of the narrative economies of these stories: What do the literary dynamics of each SOBA story tell us about how a supplicant seeks out Jesus' healing resources, how Jesus dispenses these resources, and how any tertiary characters impede or facilitate this exchange? What sorts of economic characteristics are manifested by each story's narrative pattern of exchanges?

To begin addressing these broad questions, the four SOBA accounts were considered through the interpretive lens of several exchange-based questions: Who gives and/or gets (or does not give/not get) what, when, where, to and/or from whom, and for what purpose? By applying these questions to the local economies of our four texts, a pattern of three primary exchanges emerged: the locational, healing and conflict exchanges. In my analysis of the texts below, the first step will be to delineate this general pattern of textual exchanges.

Once the general pattern is described, I will read through each SOBA account with two tasks in mind. The first aim is to describe how each of the four SOBA stories enacts the general pattern of textual exchanges, both in its conformity to and divergence from the pattern. The second goal in reading each individual pericope is to assess and name the microeconomy suggested by each story's individual pattern of exchanges. Given that Jesus is both the character who possesses the desired, limited resources, and the character who, as healer, has primary control over the allocation of these healing resources, particular attention is paid to the type of microeconomy that emerges on the part of Jesus. We know that at a macro level Jesus will heal the person

1.On the impossibility of a 'pure' gift and on the notion of 'gift' as inescapably connected to the economics of exchange, see Derrida 1992. 
for whom each supplicant pleads. But what, according to the textual exchanges, is the local cost of this healing and who must pay the price? The broad aim of this analysis is therefore to look beneath the macro-narrative of the miracle healing economy and to identify the textual microeconomies embedded within the narrative of each SOBA text. Following this analysis, I will summarise the findings and consider their implications in the light of the motivating social contexts introduced above.

Before beginning the exploration of the SOBA microeconomies, it may be wise to anticipate concerns coming from at least two quite different directions. On the one hand, some readers may object, for theological reasons, to an understanding of Jesus' healings as something other than a free gift, as part of a limited, exchange-based narrative economy. In response to this concern, however, I would offer that the Matthean text itself presents Jesus and his healing economy in ways that are limited, or at least delimited, by time, geography, physical access to Jesus and narrative genre. As concerns time boundaries, Matthew's Jesus heals only during the time of his active ministry. His first healings take place in Galilee (4:23), and his last healings take place in the temple (21:14). Matthew gives us no stories of healings during Jesus' infancy or after his arrest. Jesus' healing powers also tend to be textually presented as geographically delimited, with Jesus generally healing people where he is rather than where he is not. ${ }^{2}$ We do not read, for example, of Jerusalem-based healings attributed to Jesus while he is yet in Nazareth. This general geographic delimitation is more precisely bounded within Matthew's gospel by the prominent healing motif of physical access to Jesus. Most Matthean healing stories are predicated on physical proximity to Jesus; a person seeking healing for self or another must be near Jesus, who often effects healings through his word or his touch. ${ }^{3}$ Finally, Matthew's Jesus does not heal when he is teaching, telling parables or giving his discourses. Because healing miracles do not intrude on Jesus' extensive speeches, the text's broader generic economy can be understood as limiting access to Jesus' healing resources. Thus, while the Gospel of Matthew presents a uniformly positive outcome once Jesus' healing resources are engaged, the text equally constrains access to those resources through its construction of Jesus' healing economy as temporally, geographically, physically and generically bounded. Literarily speaking, being healed by Jesus is a matter of being in the right textual place at the right narrative time. It is the text itself, then, that portrays Jesus' healing resources as limited.

Concern over a text-based, quasi-economic analysis of Jesus' healing microeconomies may also come from a second direction. It should be noted that in the study of economics (in the strict sense), analytical focus tends to be on quantifiable material goods and services (Mai 1964:7; Reynolds 1973:3). This focus, for obvious reasons, cannot be applied wholesale in the present endeavour: the gospels' miracle healing stories are not enacted as part of a monetised economy or even as part of a bartered exchange. On one level, then, there is no cost; perhaps we are indeed in the realm of gift, and an exchange analysis is therefore inappropriate. Still, this lack of 'payment for healings received' ought not to obscure the fact that an intricate series of narrative exchanges is nonetheless enacted within each of these stories. While these exchanges may not be fiscally quantifiable, they are nonetheless textually identifiable. En route to the healing outcome, each story presents its characters as giving and taking, refusing and receiving - and all of these exchanges, all of these microeconomic moments, are clearly on display in each account. It is this narrative economy that we seek to explore and assess.

Perhaps both of these potential concerns signal a more fundamental question: Why examine biblical texts using

2.The two distance healings in the Gospel of Matthew - those of the centurion's servant and the Canaanite woman's daughter - will be considered below.

3.On physical proximity to Jesus, see, for example, Mt 4:24; $15: 30$. On word and touch, see Mt 8:2, 3, 14-16; 20:30-34. this odd hybrid of narrative economy in the first place? From among the many reasons that have prompted this study, let me name two here. Firstly, as noted above, one of my primary motivations is to find a hands-on methodology that will help students read Jesus in a more critically engaged manner. I am wondering whether a method that activates the text through the practical vocabulary of exchange might be one step towards this outcome. It may be that the application of fairly familiar economic concepts about giving and getting to fairly familiar stories about Jesus the healer will make room for some new insights about the texts and their protagonist. As such, the following approach is something of an experiment in motion. Secondly, my exegetical interests lie in the greater meeting of critical theories with practical methodologies and exegesis. A method that relies on economic exchanges to read biblical texts may well prove fruitful when used in tandem with theoretical approaches that take seriously the issues of power, politics and economics, such as postcolonialism, Marxism, neo-Marxism, liberation theologies and gender- and sex-based readings. As such, the following will hopefully function as my own early step into an already ongoing journey of collaborative interdisciplinary research.

\section{THE FOUR SOBA ACCOUNTS}

\section{A structural overview}

We turn at last to our four SOBA accounts and begin with an overview of their shared narrative exchange structure. In analysing these four accounts, a general pattern emerges - a pattern characterised by three primary exchanges between the supplicant and Jesus. The first exchange, which occurs only once, is locational: Jesus and the supplicant each exchange one locale for another. In recounting the story, the narrator first introduces Jesus and his locational exchange (or lack thereof), followed by the supplicant's. The supplicant's movement towards Jesus is sometimes accompanied by a second movement (e.g., falling at Jesus' feet). While on the surface this exchange appears to be only a literary device to get Jesus where he needs to be in order to encounter the supplicant, it ought not be overlooked as an important moment of economic parity within the text: Jesus leaves one locale for another, and the supplicant leaves a place in order to encounter Jesus. The healing encounter that follows largely depends on this equal exchange of movement.

The second exchange is the healing exchange, which consists of a cycle of exchanges between the supplicant and Jesus. Once the locational exchange is completed, the SOBA initiates the healing exchange by speaking to Jesus. The SOBA's healing request generally consists of the following elements: titular address to Jesus; statement(s) of the malady and extent of suffering; and request for healing. The order of these elements varies between stories. The healing exchange is continued by Jesus, whose healing response is expressed through: vocative address to SOBA or others (uncommon); statement(s) or action(s) indicating intent to heal; and healing speech or actions. The narrator ends this exchange with a statement concerning the time or immediacy of the healing.

The third exchange is the conflict exchange, which shows the greatest variability between the SOBA texts. This exchange always interrupts the healing exchange, thus necessitating that the healing exchange be completed at a later point in the story. The conflict exchange can involve Jesus, the SOBA, and/or tertiary characters within the pericope, and there can be more than one conflict exchange within a given story. At times the narrative tension introduced by the conflict is resolved; at times it remains unresolved. Because the conflict exchange shows so much variability, a measure of textual control in identifying this exchange was needed. Three elements mark the conflict exchange: the source of the conflict, the start of the conflict and the end of the conflict. To operationalise these more precisely, the following definitions were employed in analysing the conflict exchange: The source of conflict exchange is defined as 
TABLE 1

Primary types and elements of economic exchanges in SOBA accounts

\begin{tabular}{|c|c|c|}
\hline TYPE OF EXCHANGE & ENACTED BY & POTENTIAL ELEMENTS OF THE EXCHANGE \\
\hline \multirow[t]{2}{*}{ Locational } & Jesus & Movement onto scene \\
\hline & SOBA & Movement onto scene \\
\hline \multirow[t]{3}{*}{ Healing } & SOBA & $\begin{array}{l}\text { Healing Request: } \\
\text { Titular address to Jesus } \\
\text { Statement of malady } \\
\text { Statement of extent of suffering } \\
\text { Request for healing }\end{array}$ \\
\hline & Jesus & $\begin{array}{l}\text { Healing Response: } \\
\text { Vocative address to SOBA or others } \\
\text { Statement or action indicating intent to heal } \\
\text { Healing speech or actions }\end{array}$ \\
\hline & [Narrator] & Statement concerning time or immediacy of healing \\
\hline Conflict & $\begin{array}{l}\text { Jesus, SOBA or } \\
\text { tertiary characters }\end{array}$ & $\begin{array}{l}\text { Wide variation, but three common elements: } \\
\text { Source of conflict (whoever or whatever derails or delays the healing process) } \\
\text { Start of conflict (occurs when healing exchange is interrupted) } \\
\text { End of conflict (occurs when healing exchange is reprised, even if conflict remains unresolved) }\end{array}$ \\
\hline
\end{tabular}

whoever or whatever functions within the narrative to delay or derail the healing request; once this derailment is introduced, the conflict cycle has begun. Thus, the eventual source of the conflict exchange may appear on the scene before the conflict exchange itself begins. Because the healing exchange is invariably interrupted by the conflict exchange, the end of the latter occurs when the healing exchange is reprised, either through the SOBA's continued healing request or through Jesus' healing response. (A schematic summary of the three primary types of exchange and the elements of these exchanges can be found in Table 1)

We turn now to an exploration of each SOBA account and consider each story according to its order within the Matthean text: the centurion, the leader, the Canaanite woman, the man. A translation of each pericope precedes the analysis. The prose explication that follows each translation is accompanied by a table that endeavours to present the salient exchanges of each narrative in shorthand form.

The following prefacing notes are given. Firstly, because the healing exchange is always presented as the second exchange within each pericope and because this exchange is always interrupted by one or more conflict exchanges, the elements of the central healing exchange of each story are tracked in the tables using prime markers (i.e., 2, 2', 2"). Secondly, although the time of healing and some of Jesus' healing intentions and/ or actions are recounted by the narrator rather than through Jesus' direct speech, this element of the healing response is nonetheless listed in the tables by Jesus' name, rather than by the narrator's, as the actions are obviously attributed to the former.

\section{A subversive and exclusive economy: The story of the centurion (Mt 8:5-13)}

${ }^{5}$ Now when [Jesus] entered Capernaum, a centurion came to him, pleading ${ }^{6}$ and saying, "Lord, my servant is lying in the house paralyzed, tormented terribly." "And [Jesus] says to him, "Shall I come and heal him?" ${ }^{8}$ And the centurion answered, "Lord, I am not worthy to have you come under my roof, but only say a word, and my servant will be healed. ${ }^{9}$ For I also am a man under authority, having soldiers under me. And I say to this one, 'Go,' and he goes; and to another one, 'Come,' and he comes; and to my slave, 'Do this,' and he does." ${ }^{10}$ When he heard [this], Jesus marveled and said to the ones following, "Truly, I say to you, in no one in Israel have I found such great faith. ${ }^{11}$ And I tell you that many from east and west will come and recline at the table with Abraham and Isaac and Jacob in the kingdom of heaven. ${ }^{12} \mathrm{But}$ the sons [and daughters] of the kingdom will be thrown into the outmost darkness. There will be weeping and gnashing of the teeth." ${ }^{13}$ To the centurion Jesus said, "Go. Let it be done for you as you believed." And [his] servant was healed in that hour.

(Mt 8:5-13)

The story of the centurion - likely a low-ranking gentile officer overseeing about 100 soldiers (Luz 2001:9, 10) - begins with a locational exchange as Jesus enters Capernaum and is approached by the centurion, who comes to plead for the healing of his bedridden and paralysed servant (see Table 2). The centurion's healing request begins with a titular address, 'Lord', and continues with statements describing the malady and suffering of the servant. Uniquely, the centurion does make an explicit request for healing, at least not before Jesus asks, perhaps with astonishment or annoyance, 'Shall I come and heal him?'t Notice that Jesus seems to assume another locational exchange is needed: he, Jesus, will have to go somewhere else to heal the suffering servant. When read as a rhetorical rebuff, Jesus' reply halts the healing exchange initiated by the centurion and introduces the conflict exchange. Jesus himself, then, initiates the conflict exchange.

The centurion engages Jesus' apparent objection not by denial but rather by assent. In verse 8 , the centurion repeats the title, 'Lord', and explicitly affirms, using the same verb of motion used by Jesus in his response, ${ }^{5}$ that he, the centurion, is unworthy to have Jesus come under his roof. Thus, he allows Jesus' objection and articulates the conflict implicit in Jesus' rhetorical question. Having accepted Jesus' objection, however, the centurion then goes on to propose an alternate exchange based not on location but rather on words: 'but only speak a word and my servant will be healed' (Mt 8:8). Here the centurion voices his healing request, which is spoken more as a healing assumption: Jesus has only to speak and, by means of his word, the servant will be healed. The centurion goes on to describe this word-based economy via an analogy of his power with Jesus'. He states that while he is a man under the command of others, he also has command over others - soldiers and slaves - to whom he has only to give an order and it is accomplished. The centurion defines the efficacy of his imperatives in terms of the physical proximity of the one receiving the order, as suggested by the

4.The preponderance of commentators seems to interpret Matthew 8:7 as a rhetorical question rather than a statement, and understand by the question that Jesus is problematising the centurion's implicit demand on account of the latter's ethnicity. See, for example, France 2007:312, 313; Held 1963:194, 195; Luz 2001:10 Nolland 2005:354, 355. On reading interrogative meanings from seemingly direct statements, see Smyth 1984, § 2641. However, Hagner (1993:204) reads this verse as a statement, assuming $Q$ intended it as such, as evidenced by the Lukan author's portrayal of Jesus' willing movement towards the centurion's house in Lk 7:6.

5. The verb is 'erxomai: In Jesus' rebuff, the verb is an aorist active participle, nominative, masculine, singular; in the centurion's reply, the verb is a second person singular aorist active subjunctive. 
TABLE 2

Overview of exchanges and micro-economies in Matthew 8:5-13

A subversive and exclusive economy: The story of the centurion

\begin{tabular}{|c|c|c|c|c|c|}
\hline EXCHANGE \# & TYPE & $\begin{array}{l}\text { SPEAKER/ } \\
\text { ACTOR }\end{array}$ & DELINEATION & NARRATIVE IN BRIEF & $\begin{array}{l}\text { IMPLIED ECONOMIES AND NOTES ON } \\
\text { EXCHANGES }\end{array}$ \\
\hline 1 & Locational & $\begin{array}{l}\text { Jesus } \\
\text { SOBA }\end{array}$ & $\begin{array}{l}\text { Jesus' } \\
\text { movement } \\
\text { SOBA's } \\
\text { movement }\end{array}$ & $\begin{array}{l}\text { Jesus enters Capernaum } \\
\text { Centurion approaches, pleading }\end{array}$ & \\
\hline 2 & $\begin{array}{l}\text { Healing } \\
\text { request }\end{array}$ & SOBA & $\begin{array}{l}\text { Titular address } \\
\text { Statement of } \\
\text { malady } \\
\text { Statement of } \\
\text { suffering } \\
\text { Request }\end{array}$ & $\begin{array}{l}\text { Lord } \\
\text { Servant is bedridden \& paralysed } \\
\text { Suffers terribly } \\
\text { [none] }\end{array}$ & $\begin{array}{l}\text { Healing request not voiced until after conflict } \\
\text { is introduced }\end{array}$ \\
\hline \multirow[t]{3}{*}{3} & $\begin{array}{l}\text { Conflict } \\
\# 1\end{array}$ & Jesus & $\begin{array}{l}\text { Rebuffs } \\
\text { unvoiced } \\
\text { healing request }\end{array}$ & Shall / come and heal him? & \multirow{3}{*}{$\begin{array}{l}\text { Jesus assumes a second locational } \\
\text { exchange will be needed and reacts } \\
\text { negatively to this. The centurion proposes an } \\
\text { alternate plan by which Jesus may heal the } \\
\text { servant, and Jesus agrees to it }\end{array}$} \\
\hline & $\begin{array}{l}\text { Attempt to } \\
\text { resolve } \\
\text { conflict }\end{array}$ & SOBA & $\begin{array}{l}\text { Titular address } \\
\text { Assent } \\
\text { Healing request } \\
\text { Statement } \\
\text { of command } \\
\text { micro-economy }\end{array}$ & $\begin{array}{l}\text { Lord } \\
\text { I am not worthy } \\
\text { Only say a word and my servant will } \\
\text { be healed } \\
\text { I give a command and it is done; it is } \\
\text { more so for you }\end{array}$ & \\
\hline & Conflict resolution & Jesus & $\begin{array}{l}\text { Statement of } \\
\text { approval }\end{array}$ & $\begin{array}{l}\text { I have not found anyone else in Israel } \\
\text { with such great faith }\end{array}$ & \\
\hline 4 & $\begin{array}{l}\text { Conflict } \\
\# 2\end{array}$ & Jesus & $\begin{array}{l}\text { Proposal of } \\
\text { subverting, } \\
\text { excluding } \\
\text { economy }\end{array}$ & $\begin{array}{l}\text { Many outsiders will become insiders; } \\
\text { insiders will become outsiders }\end{array}$ & $\begin{array}{l}\text { Proposed economy is subversive but also } \\
\text { exclusive: insiders will thrown into dark, } \\
\text { painful places. Conflict not resolved in this } \\
\text { story }\end{array}$ \\
\hline 2' & $\begin{array}{l}\text { Healing } \\
\text { response }\end{array}$ & Jesus & $\begin{array}{l}\text { Healing } \\
\text { command } \\
\text { Time of healing }\end{array}$ & $\begin{array}{l}\text { Go, let it be done for you as you } \\
\text { believed } \\
\text { Servant healed in that hour }\end{array}$ & \\
\hline
\end{tabular}

three dative indirect objects in 8:9: 'I say to this one... and to another... and to my slave.... In $8: 8$, when the centurion first introduces his alternative economy to Jesus, he issues an imperative to Jesus using a different form of the same verb, 'say': 'but only say a word... ${ }^{6}$ However, this imperative to speak is not followed by an indirect object, a person who will hear and execute Jesus' command; rather, the centurion seems to locate the efficacy of Jesus' healing command in the very fact of his speaking, in the instrumentality of the word he will utter. Thus, while the centurion understands analogically Jesus' power and his own, his analogy nonetheless recognizes that Jesus' power is greater, depending neither on human agency nor physical proximity to be accomplished.

The centurion, then, proposes a command microeconomy, and Jesus' response to this alternate exchange is striking: Jesus 'marvels' (v. 10). ${ }^{7}$ This is the first time this verb appears in the Matthean gospel, and it is the only time it will be used to describe Jesus' response. In subsequent verses, this verb will be employed to describe others' amazed reactions to Jesus. ${ }^{8}$ As for Jesus, in his amazement, he approves the centurion's alternate economy and interprets it as indicative of a great faith unlike anything else he has yet found in Israel (v. 10). By approving the centurion's proposed command economy and by relinquishing his own assumption of the needfulness of a locational exchange, Jesus resolves the conflict that he himself introduced with his rhetorical question in 8:7.

6. The verb is legō. When referring to Jesus in verse 8 , the verb is a second person aorist active imperative; when referring to himself in verse 9 , the verb is a first person present active indicative.

7. Thaumazō in the aorist active indicative, third person singular.

8.In later verses, thaumazō will be used to describe responses to Jesus' actions (Mt $8: 27 ; 9: 33 ; 15: 31 ; 21: 20)$, words $(22: 22)$ and wordlessness $(27: 14)$.
Before moving on, let us pause to note the textual trajectory of the centurion's word-based microeconomy. As the Matthean text proceeds beyond this story, we will next hear of Jesus healing Peter's mother-in-law. Just after that, in 8:16, Jesus is healing demon-possessed people and casting out spirits 'with a word.' This is the first time the Matthean Jesus, without prompting, will use his word as an explicit and sufficient instrument of healing. Given the proximity of this pericope to that of the centurion and given the syntactic similarities between the two dative constructions, 'with a word', in 8:8 and 8:16, we might wonder whether the words of the centurion revealed to Jesus more than the former's great faith. The centurion, despite his status as an imperial representative, despite his possible status as an ethnic outsider, seems textually staged to reveal to Jesus a dimension of his power of which he himself was not yet aware: By encountering the centurion, Jesus learns the commanding power of his word as a means of healing.

Returning to our story, Jesus has just affirmed the great faith of the centurion, thereby resolving the conflict introduced by his own hesitancy to go to the house of the centurion. In his very next statement, however, Jesus introduces a second conflict, one that seems to derive from Jesus' generalised understanding of the centurion's explanation and faith: Jesus states that many from east and west will come and recline at table with the great patriarchs of the faith in the kingdom of heaven. Those who are presently sons [and daughters] of the kingdom, however, will be thrown out into a place of outmost darkness, with tears and gnashing teeth (vv. 11, 12). This second conflict, let us note, is not resolved within the pericope. Instead, at this moment of heightened narrative tension Jesus issues a command to the centurion to 'go', to which he adds the indirect healing command 'let it be for you as you believed' (v. 13). The story concludes with a statement of the immediacy of the servant's cure. 
TABLE 3

Overview of exchanges and micro-economies in Matthew 9:18, 19, 23-26

A transgressive economy: The story of the leader whose daughter died

\begin{tabular}{|c|c|c|c|c|c|}
\hline EXCHANGE \# & TYPE & $\begin{array}{l}\text { SPEAKER/ } \\
\text { ACTOR }\end{array}$ & DELINEATION & NARRATIVE IN BRIEF & IMPLIED ECONOMIES AND NOTES ON EXCHANGE \\
\hline 1 & Locational & SOBA & $\begin{array}{l}\text { Jesus' movement } \\
\text { SOBA's movement }\end{array}$ & $\begin{array}{l}\text { [none] } \\
\text { Ruler comes to Jesus and falls } \\
\text { at his feet }\end{array}$ & $\begin{array}{l}\text { Only SOBA story begun without Jesus' movement onto } \\
\text { the scene }\end{array}$ \\
\hline \multirow[t]{2}{*}{2} & $\begin{array}{l}\text { Healing } \\
\text { request }\end{array}$ & SOBA & $\begin{array}{l}\text { Titular address } \\
\text { Statement of malady } \\
\text { Request }\end{array}$ & $\begin{array}{l}\text { [none] } \\
\text { My daughter just died } \\
\text { Come and lay your hand on her } \\
\text { and she will live }\end{array}$ & \multirow{2}{*}{$\begin{array}{l}\text { Only story where SOBA uses no titular address. Leader } \\
\text { assumes a transgressive economy; Jesus does not } \\
\text { argue with or deny the assumption. } \\
\text { Both Jesus and leader assume change of location is } \\
\text { needed for healing }\end{array}$} \\
\hline & Healing response & Jesus & Action of intent & $\begin{array}{l}\text { Gets up and follows with } \\
\text { disciples }\end{array}$ & \\
\hline \multirow[t]{2}{*}{3} & \multirow[t]{2}{*}{ Conflict } & Jesus & Statement of malady & Go away; she's only sleeping & \multirow[t]{2}{*}{ Jesus assumes transgressive economy; crowd rejects it. } \\
\hline & & Crowd & $\begin{array}{l}\text { Rejection of } \\
\text { statement }\end{array}$ & Ridicules him and is put outside & \\
\hline 2' & $\begin{array}{l}\text { Healing } \\
\text { response, } \\
\text { continued }\end{array}$ & Jesus & $\begin{array}{l}\text { Healing actions } \\
\text { Healing response } \\
\text { Time of healing } \\
\text { Result of healing }\end{array}$ & $\begin{array}{l}\text { Goes in and grasps her hand } \\
\text { The girl gets up } \\
\text { [none] } \\
\text { Report goes out into all the } \\
\text { region }\end{array}$ & $\begin{array}{l}\text { Only story without specified time of healing, though } \\
\text { immediacy is clear in the narrative }\end{array}$ \\
\hline
\end{tabular}

If the centurion's microeconomy can be described as a type of literary command economy, what can we say about the microeconomy enacted by Jesus in this story? Jesus' local economy demonstrates two primary characteristics. On the one hand, it appears to be a subversive economy that disturbs statusquo notions; on the other, it is an exclusive economy from which some will be forcibly removed. We read the subversive economy in Jesus' statement that many outsiders will become insiders fit to dine even with the patriarchs (v. 11). Thus, the Matthean Jesus' microeconomy of subversion suggests that those who, at first appearance, seem immovably positioned outside Israel can, in fact, be included within Israel. Notice, however, that Jesus' lineblurring microeconomy emerges only as the story develops; Jesus himself does not seem to understand the permeability between outsider and insider when he gives his rhetorical interruption back in 8:7. What, we may wonder, induces his apparent change of heart? From a narrative perspective, the intervening variable is the speech of the centurion and the faith it demonstrates to Jesus. The words of the centurion, while not efficacious for healing, are nonetheless instrumental in changing Jesus' mind about outsiders, thereby allowing the potentially subversive microeconomy to emerge.

With regard to outsiders, Jesus' local economy appears not only subversive but also fairly inclusive. Let us note, however, that the text does not indicate that all outsiders will become insiders. The use of the word polloi, which expresses 'many', and even 'a great many' (Arndt \& Gingrich 1952: s.v. polus), is not all inclusive; it does not mean 'all'. Still, the fact that not all outsiders will become insiders seems syntactically connected to the fact that not all outsiders will come to recline with the patriarchs; there is nothing within the text to suggest that outsiders seeking to be included in the company of the patriarchs will be rejected upon arrival.

Whereas those coming from east and west will be included, the same happy end does not await those who are named by Jesus as sons [and daughters] of the kingdom. In verse 12, Jesus goes on to say that this group, seemingly in its entirety, will be cast out into the outmost darkness. Thus, Jesus' subversive microeconomy continues to be evident, although here it is not one that leads to greater inclusion but rather one that leads to categorical exclusion. According to Jesus, not everyone will be included in the company of the patriarchs in the kingdom of heaven. Indeed, it is those whom Jesus calls sons [and daughters] of the kingdom, those whom he names most clearly as insiders, who appear most at risk of catastrophic exclusion.
What is the criterion upon which this expulsion is predicated? The reason for their exclusion is not made explicit in the text, although it, too, seems connected to the words of the centurion and the great faith Jesus hears therein. Faith is the implicit reason why many outsiders will come, and so be included. Conversely, the expulsion of the kingdom's progeny would seem to be the result of a faith that is somehow insufficient. Notice that the narrative does not present Israel as lacking faith; when comparing the faith of the centurion to that of the members of Israel, Jesus says that the former's is greater, not that the latter's is necessarily absent. We are left wondering: What is the threshold of faith necessary and sufficient to avoid expulsion from the kingdom? Finally, we cannot help but observe that Jesus' subversive blurring of the lines between insiders and outsiders, while good news for those presently on the outside, is unhappy news indeed for those identified by Jesus as sons [and daughters] of the kingdom. Their future sufferings are clearly delineated; alas, the same cannot be said for whatever remedial steps might spare them this fate. On this account, the story of the centurion speaks not so much as a word.

\section{A transgressive economy: The story of the leader whose daughter died (Mt 9:18, 19, 23-25) ${ }^{9}$}

${ }^{18}$ While saying these things to them, just then a certain ruler came and fell before him saying, "My daughter has just now died. But come and lay your hand upon her, and she will live." ${ }^{19}$ And Jesus got up and, with his disciples, followed him.... ${ }^{23}$ Then Jesus went into the house of the ruler and saw the flute players and the crowd making a commotion. ${ }^{24} \mathrm{He}$ was saying, "Go away, for the girl did not die, but she is sleeping." But they were laughing at him. ${ }^{25} \mathrm{But}$ when the crowd was put out, he went in and grasped her hand, and the girl got up. ${ }^{26}$ And this report went out into all that region.

(Mt 9:18, 19, 23-25)

At a glance, as Table 3 indicates, this SOBA text alone begins without the expected locational exchange; instead of Jesus moving into the area, we have only the leader coming to Jesus and falling at his feet, thereby interrupting Jesus' conversation with John's disciples (vv. 14-18). As in the story of the centurion, the leader approaches Jesus alone; the daughter for whom he is seeking restored life lies at a distance. The leader initiates his healing request without any titular address toward Jesus; instead, his healing request begins with a statement of the

9. Textually, this story surrounds the account of the bleeding woman who is healed (vv. 20-22). Because the focus here is on the SOBAs, her story is not included. However, the literary and economic dynamics connecting these two stories surely merit consideration at another time. 
ultimate malady: 'My daughter has just died'. His actual healing request is the most detailed of any SOBA story, seeking as it does a locational exchange ('come'), a specific healing action ('lay your hand upon her') and an explicit expected outcome ('she will live').

Jesus' healing response begins with a physical indication of his healing intent: he and his disciples immediately get up and follow the ruler. Unlike the centurion, who assumed the sufficient efficacy of Jesus' word, the ruler indicates his assumption that the physical presence of Jesus, indeed, the physical touch of his hand upon his daughter's lifeless body, is necessary for a successful healing outcome. For his part, Jesus does not counter the leader's petition with a statement of the instrumentality of his word. Instead, he wordlessly accedes to the ruler's scenario for healing by getting up and following him, the only occasion in the whole of Matthew's gospel when Jesus will 'follow' anyone.

Upon arrival at the ruler's home, and before the healing response is continued, the conflict exchange is inserted. Inside the house, Jesus encounters the flute players and the noisily lamenting crowd. The musicians were likely hired for the sad occasion; the members of the crowd may be professional mourners or family and friends (France 2007:364; Nolland 2005:397, 398). Certainly, the death of the daughter is not questioned inside the house; the mourning and grieving are well underway. The conflict exchange is initiated when, above the din of the crowd, Jesus tells the mourners to go away because the girl is not dead, only sleeping, in response to which the crowd laughs at Jesus, apparently ridiculing his sight-unseen diagnosis. The conflict exchange ceases when the mourning, mocking crowd is put outside.

Two elements of this conflict exchange gain our attention. Firstly, we notice that Jesus initiates the conflict on two levels: his statement about the girl being asleep contradicts not only the mourners' and the ruler's understanding of reality, it equally contradicts our own narrative expectations as readers and hearers of the text. Jesus' words thus create a conflict both within the dynamics of the text itself and between the text and its consumer. Secondly, although it is Jesus who introduces this conflict, it is clearly the assembled mourners who are staged as the temporary impediment to the healing process: once they are put outside, the healing will take place. They become Jesus' narrative opponents because they start laughing when he says the girl is not dead. And yet, the narrative presents pipers and a lamenting crowd inside the ruler's house. If anything could raise a sleeping child, surely it would be a commotion such as this! Indeed, we note in 9:24 that Jesus' words, 'Go away, for she did not die but is sleeping', is preceded by an imperfect form of the verb 'to say', as if Jesus himself has to keep repeating himself in order to be heard above the din of the mourners. No wonder the crowd laughs at Jesus when he finally gets their attention: his words contradict both their experience as mourners and funeral musicians and their immediate narrative noise. Thus, the crowd mocks Jesus because his words make no sense, and yet their laughter, which is perfectly logical given the narrative set-up, earns them their textual position as Jesus' opponents.

Once the crowd is put outside, the healing exchange is quickly brought to completion when Jesus goes in and grasps the girl's hand, and she is raised. Jesus' healing actions are thus described in a manner parallel to the ruler's original petition: 'come and lay your hand upon her, and she will live' (9:18). More than this, however, the conclusion of the healing exchange serves to inform us as readers and hearers of the text that the ruler and Jesus are correct in their assumptions. The father assumes that his daughter is dead but that Jesus can return her to life. And Jesus, regardless of the girl's condition, assumes that he can restore the girl to life. Through the healing exchange, then, the father's faith is vindicated, Jesus' life-altering power is highlighted, and the crowd's derisive laughter is proved unfounded. In a way, this verse resolves the story's conflict: Jesus was right, and the crowd was wrong.

The narrative conflict between the mourners and Jesus is further resolved in verse 26 , which states 'this news went out into all that region'. This verse serves the function of letting readers and hearers know that the off-stage mourners also are aware of the outcome of the event. An auditory exchange occurs in the narrative as the sounds of grief are replaced by the news of restored life. As the happy report ripples outward from the ruler's house, through the streets, to the next town and then the next, readers can assume that the musicians and the mourners, those who bemoan life's end and likely never see any outcome save death, now know that life can sometimes, somehow, emerge out of death. They have not witnessed the healing exchange, but they have heard of it. They have heard the good news.

Having arrived at the end of our narrative, what can we say about its local narrative economies? Firstly, let us again note the element of exclusion that appears in this text: The pipers and lamenting crowd are thrown out of the house. The reason for their exclusion is that they are doing the wrong thing (mourning) at the wrong time (the girl has not died), at least according to Jesus. The mourners and funeral musicians cannot imagine an outcome other than death in the wake of death. They believe that dead people are dead and stay dead, so they weep and wail for the death of the daughter. It is their mourning that secures their dismissal by Jesus.

While there are elements of exclusion in this story, they do not seem to form the central microeconomy. Instead, the predominant microeconomy revealed in this account is one that is singularly and strongly transgressive, by which is meant an economy that violates the expected or normal rules of exchange. Despite the apparent finality of his daughter's condition, the leader nonetheless voices a petition for healing that is astonishing, not only for its obvious assumption of a transgressive economy - the leader assumes that Jesus can raise the dead - but also for the forthright boldness that undergirds the assumption. The leader does not frame his request in the language of conditional possibility but rather of future certainty: 'Come and lay your hand upon her and she will live'. He assumes that Jesus can transgress the economy of death and so exchange it for life.

Equally as striking as the leader's assumption of a transgressive economy is Jesus' tacit acceptance of this economy. He does not attempt to dissuade the leader or lower his expectations. It is not to the ruler that he says the daughter is merely sleeping. Indeed, he does not speak a word to the ruler but merely gets up and follows him to the house where life has turned to death. Jesus' acceptance of the transgressive economy is further evidenced when he names this not-death-but-life economy aloud to the gathered crowd, which, unwilling or unable to imagine such an exchange, responds laughingly. The leader's and Jesus' faith in this transgressive economy is justified, however, when the ultimate exchange of life into death is undone by the girl's restoration.

\section{An inclusive and sufficient economy: The story of the Canaanite woman (Mt 15:21-28)}

${ }^{21} J e s u s$ went out from there and withdrew into the districts of Tyre and Sidon. ${ }^{22}$ ust then, a Canaanite woman from that region came out and was shouting out, "Have mercy on me, Lord, Son of David. My daughter is severely demon-possessed." ${ }^{23}$ But he did not answer her a word. Then his disciples approached him and were urging him, saying, "Send her away, because she is shouting out after us." ${ }^{24}$ But he answered and said, "I was sent only to the lost sheep of the house of Israel." ${ }^{25}$ But she came and fell before him saying, "Lord, help me." ${ }^{26} \mathrm{He}$ answered, "It is not good to take the children's bread and throw it to the dogs." ${ }^{27}$ But she said, "Yes, 
TABLE 4

Overview of exchanges and micro-economies in Matthew 15:21-28

An inclusive and sufficient economy: The story of the Canaanite woman

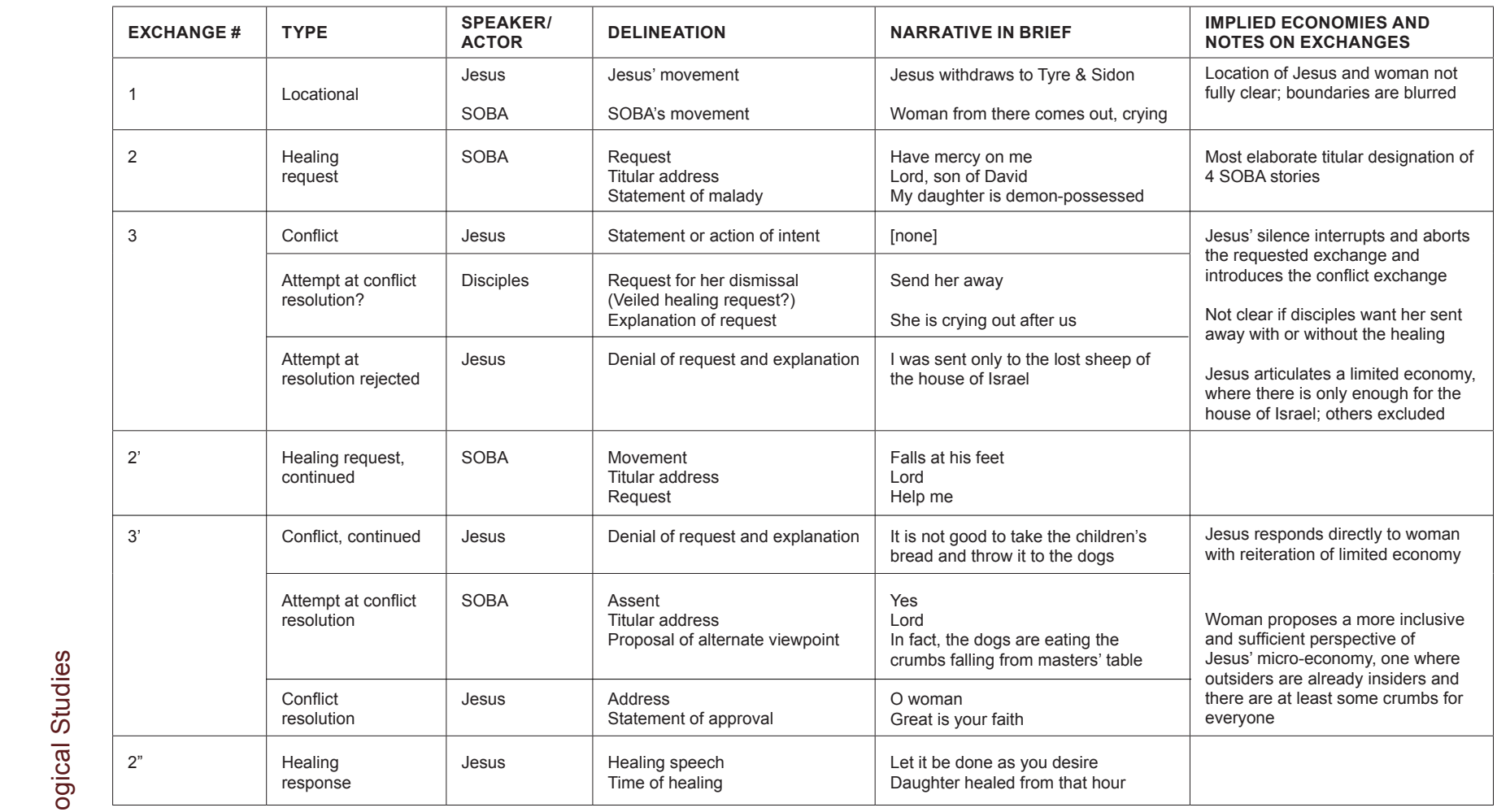

Lord. For, in fact, ${ }^{10}$ the dogs are eating the crumbs falling from their lords' table." ${ }^{28}$ Then Jesus answered her, "O woman, great is your faith. Let it be done for you as you desire." And her daughter was healed from that hour.

(Mt 15:21-28)

Given the textual identification of this story's lead female character as a non-Israelite, Jesus' earlier pronouncement to the centurion of a subverted economy wherein outsiders can become insiders (8:11) would seem to be very good news for the Canaanite woman, who asks Jesus to heal her daughter. Alas, such is not the case, at least initially. Our story begins with a blurry locational exchange: Jesus leaves Gennesaret (14:34) and withdraws into the regions of Tyre and Sidon. The Canaanite woman comes from those regions (see Table 4). Somewhere along these indistinct boundaries, the woman encounters Jesus. This woman, the first female character granted direct voice in the Matthean gospel, initiates her healing request by crying out to Jesus to have mercy on her, rather than on her daughter. Following her plea for mercy, she addresses Jesus with a double titular designation, 'Lord, Son of David', the most elaborate of the SOBA stories. To these titles, she adds a statement of her daughter's malady: she is severely demon-possessed (15:22). Her request is fully aborted by Jesus, however, who gives no indication of any intent to heal but rather ignores her completely (v. 23). As in the story of the centurion, then, Jesus rebuffs the initial healing request by a character textually staged as outside ethnic Israel. Once again, Jesus himself introduces the first element of conflict by derailing the desired healing as soon as the request is made.

The disciples, mute witnesses at most in the previous two SOBA accounts, then speak up: 'Send her away, because she is shouting out after us'. Through their words, we learn that the woman, like the centurion, has not been dissuaded by Jesus' refusal. Rather, she has become a follower in her own right, trailing after Jesus and the disciples and shouting after them in a way that has caught at least the disciples' ear. The narrative gives us

10.Liddell \& Scott 1996, s.v. kai gar, Smyth 1984, §2814. a rather clamorous scene: The woman is crying out over and over on behalf of her daughter. For their part, as suggested by the text's use of the imperfect form of erōtaō, the disciples are iterating their own urgent plea, repeatedly asking Jesus to send her away. Surrounded on all sides by importunate demands, Jesus finally responds: 'I was sent only to the lost sheep of the house of Israel' (v. 24), an economy that seems to contradict dramatically the one of welcomed outsiders expressed by Jesus in the story of the centurion (Mt 8:11). ${ }^{11}$

As Jesus makes this reply, the narrative does not tell us to whom he is addressing his words. How we interprethis audience makes a difference to how we interpret this first conflict exchange. On the one hand, we can read Jesus' response as accommodating the disciples' request to get rid of the woman. They cannot drive away the importuning woman, so they ask Jesus to take care of it, and he obliges. In this case, his primary addressee is the woman herself. Read thus, the disciples are co-opponents with Jesus against the woman; like Jesus, the disciples are opposing the woman's pleas (Wainwright 1994:671). Certainly, the text amply allows such an interpretation, both of the Matthean text in general and of the disciples' role in particular. Through a wide-angle lens, we observe that the Matthean gospel, in contrast to the Lukan gospel, never connects the verb 'apoluo (send away) with the positive outcome of a healing miracle ( $c f$. Lk 8:38; 13:12; 14:4). More to the point of the disciples' behaviour, we have already heard the disciples try to solve a problem by commanding Jesus to make it go away. In Mt 14:15, when faced with the potentially clamorous din of 5,000 hungry men, plus women and children (14:21), the disciples urge Jesus to send the crowds away so they can buy food for themselves. ${ }^{12}$ It is not

11.The words, 'the lost sheep of the house of Israel', have already appeared in Mt 10:6 as part of Jesus' first commissioning of the disciples. Here, Jesus draws a very clear line between the house of Israel on the one hand and Gentiles and Samaritans on the other (Mt 10:5). Inasmuch as this boundary is erased in the gospel's final commissioning (Mt 28:18-20), where Jesus commands the disciples to make disciples of all nations, we cannot but appreciate the role and trajectory of the the shifting geographic focus of the post-resurrection disciples. 
difficult to imagine the disciples reissuing the same imperative in the hopes that Jesus will dismiss this woman, thereby compelling her to solve her own problem elsewhere.

While it is reasonable, then, to read the disciples as compounding the narrative conflict, as erecting even higher textual barriers for the woman to scale before obtaining her daughter's healing, the text also allows a reading whereby the disciples' words can be interpreted as a veiled request for healing, especially if we understand Jesus' reply in verse 24 as directed primarily to the disciples themselves. The woman, unmanned and alone, named by the narrator as an outsider, and completely ignored by Jesus, has, despite her textual vulnerability, persevered in crying out after the disciples. Perhaps these latter, hearing the woman's insistent shouting, come to recognise that she will not go away until her petition for her daughter has been granted, in which case their appeal to Jesus to dismiss her equally holds a request for healing (France 2007:593). For their part, the disciples are textually presented as imitating the woman's strategy: They approach Jesus and repeatedly ask him to send her away. In this scenario, Jesus' words are more a response to the pestering disciples than to the woman, though she, too, may have heard his reply if within earshot. Such a reading seems especially plausible if we read the 'o de constructions in 15:23 and 15:24 as parallel rejoinders: In $15: 22,23$, the woman was crying out for mercy, 'but he ('o de) did not answer her a word'. In 15:23, 24, the disciples were asking him to dismiss the shouting woman, 'but he ('o de) said, "I was sent only to the lost sheep of the house of Israel."' By this second interpretation, the disciples are no longer operationalised as the woman's opponents. Instead, they function textually as mediators in the conflict initiated by Jesus, trying to bring about a resolution, even if for no more compassionate a reason than their own auditory relief.

The disciples' role in the conflict exchange, then, is ambiguous. They may be opponents, or they may be mediators. However, no such ambiguity seems to attend Jesus' two reactions. His first response, silence, initiates the conflict that impedes the fulfillment of the woman's healing request. His second response, a statement in which he clearly refuses to help anyone who does not figure among the lost sheep of Israel, disallows the disciples' potential resolution to the conflict and instead sustains the conflict exchange. Regardless of the disciples' role in the first conflict exchange, then, it is clear that Jesus actively creates and prolongs it.

As we return now to the narrative in the wake of the unresolved first conflict exchange, we find the woman still undeterred as she reprises her request for healing. Falling at Jesus' feet, she issues another plea: 'Lord, help me' (v. 25). Jesus indicates no immediate intent to heal, acting once again as the impediment to the woman's request for healing and thereby reprising the text's conflict exchange. This time, however, the woman's plea to Jesus at least earns her a direct reply: 'It is not good to take the children's bread and throw it to the dogs' (15:26). The lost sheep of 15:24 become children in this parable, and those outside the house of Israel, including the woman, are called dogs, which are earlier described in this gospel as unclean, like swine (Mt $7: 6)$. Once again, then, Jesus is presented as excluding, in this case both the woman and all whom Jesus names as outsiders.

Despite this stinging rebuff, the woman appears undaunted and talks back to Jesus: 'Yes, Lord. For, in fact, the dogs are eating the crumbs falling from their lords' table' (v. 27). Like the centurion, the woman initially assents to Jesus' excluding statement. Like the centurion, she will push Jesus towards an understanding beyond his present point of view. She accomplishes this by cleverly combining elements of both of Jesus' excluding statements into a new, more inclusive scenario. Jesus' initial verbal rebuff locates the woman outside the house

12.The verb, 'send away', is 'apoluō. In both $14: 15$ and 15:23, the verb is an aorist active imperative, second person singular. of Israel, and his second one compares her to an unclean dog. In her retort, the woman does not take issue with Jesus' fourlegged insult; instead, she uses the dog metaphor as a vehicle by which to challenge Jesus' understanding of her and others as outsiders. According to the woman, the dogs are inside the house, in the very space where the family eats. By the woman's telling, the dogs are still dogs; she does not claim them to be children. Nonetheless, the dogs are allowed inside the house; indeed, they are already there.

The woman's words serve to challenge Jesus' notion not only of outsiders in general but also of herself as an outsider in particular. In her reply, the woman uses a form of the word kurios for the fourth time in this story. The first three times $(15: 22,25,27 a)$, she has used this word vocatively to address Jesus with respect as 'sir' or 'lord'; indeed, we note that every time this character is granted utterance in the narrative, she addresses Jesus as 'Lord'. Thus, when the genitive plural of this same word is used in verse $27 \mathrm{~b}$ to position the dogs at their lords' table, it is not hard to draw out the narrative implication: The woman is claiming Jesus as lord of the table near which she stands. She may figure among the 'dogs', but she is naming herself as an insider, already within Jesus' house, already near his table.

The woman's transformation of Jesus' excluding dogs metaphor is accomplished not only by locating the dogs within the house but also by shifting the motion of the verbs. In his rebuff, Jesus argues against throwing the children's bread to the dogs; in her retort, the woman agrees, 'Yes, Lord', but counters Jesus' scenario with the alternate viewpoint that, in fact, no one is actively throwing the children's food to the dogs; rather, the bread is served at the lords' table, and the dogs are merely eating the falling crumbs. The woman's clever use of the word, 'crumbs', following the word, 'bread', and her explicit introduction of a table undo Jesus' image of food wrongfully taken from hungry children and carelessly tossed to dogs. Instead, the woman's scenario is one where those rightfully at the table eat the choice food that is served. What is more, this fare seems adequate to fill the diners because they do not jealously guard and hungrily devour every speck of food; instead, they have the small luxury of dropping bits and crumbs, and these scraps are licked up by the dogs allowed inside the house.

Whereas Jesus identified the woman as an outsider beyond the scope of his ministry to the house of Israel and as an interloper wrongfully seeking what belongs to others, the woman's skilfully constructed argument converts Jesus' understanding, as evidenced by his reply: 'Oh, woman, great is your faith. Let it be done for you as you desire' (15:28). Now Jesus addresses the woman vocatively, not only mirroring her respectful addresses to him throughout the pericope, but also recognising her, at last, as a woman, a person. He then names her faith as 'great' and issues the passive and indirect healing command that not only resolves the story's conflict cycle but also equally restores the woman's daughter that very hour.

In analysing the microeconomy of this account, we encounter what appears to be one economy viewed from two different perspectives. Jesus initially speaks of a household-based economy that is exclusive and seemingly limited. From his perspective, there is only enough for those inside the house of Israel. For her part, the woman initially accepts the framework of this microeconomy ('yes, Lord' [v. 27]); however, she then suggests a lens with a wider angle, one that allows Jesus to see more clearly the reality of this limited economy as she perceives it. And this reality, according to the woman, is one where the little dogs are already near the table, gulping down the bits dropped by those at their masters' table. The woman, then, is not proposing an alternative economy. In fact, she seems to understand, as does Jesus, a limited economy where there is no sense of overflowing super-abundance; no one is putting platters of choice food in front of the dogs. And yet, while there is no sense of surplus in her microeconomy, there is inclusion and there is adequacy. There is an assumption of enough for everyone. 
TABLE 5

Overview of exchanges and micro-economies in Matthew 17:14-18 (In)complete economies: The story of the man with the epileptic son

\begin{tabular}{|c|c|c|c|c|c|}
\hline EXCHANGE \# & TYPE & $\begin{array}{l}\text { SPEAKER/ } \\
\text { ACTOR }\end{array}$ & DELINEATION & NARRATIVE IN BRIEF & $\begin{array}{l}\text { IMPLIED ECONOMIES AND NOTES ON } \\
\text { EXCHANGES }\end{array}$ \\
\hline 1 & Locational & $\begin{array}{l}\text { Jesus } \\
\text { SOBA }\end{array}$ & $\begin{array}{l}\text { Jesus' movement } \\
\text { SOBA's movement }\end{array}$ & $\begin{array}{l}\text { Jesus comes down from mountain } \\
\text { A man comes to Jesus and kneels before him }\end{array}$ & First healing after transfiguration \\
\hline 2 & $\begin{array}{l}\text { Healing } \\
\text { request }\end{array}$ & SOBA & $\begin{array}{l}\text { Titular Address } \\
\text { Request } \\
\text { Statement of Malady } \\
\text { Statement of Suffering } \\
\text { Explanation of Malady }\end{array}$ & $\begin{array}{l}\text { Lord } \\
\text { Have mercy on my son } \\
\text { He is epileptic } \\
\text { He suffers terribly } \\
\text { He falls into the fire and water }\end{array}$ & \\
\hline \multirow[t]{2}{*}{3} & $\begin{array}{l}\text { Anterior } \\
\text { healing } \\
\text { request }\end{array}$ & SOBA & Request for healing & I brought him to your disciples & \multirow{2}{*}{$\begin{array}{l}\text { Interrupted or incomplete economy: father } \\
\text { attempts the exchange, but disciples are } \\
\text { unable to fulfill request and complete the } \\
\text { transaction } \\
\text { Disciples' failure derails healing request and } \\
\text { is therefore source of first conflict }\end{array}$} \\
\hline & $\begin{array}{l}\text { Anterior } \\
\text { response: } \\
\text { Conflict } \\
\# 1\end{array}$ & Disciples & $\begin{array}{l}\text { Attempted healing } \\
\text { action }\end{array}$ & They could not heal him & \\
\hline 4 & $\begin{array}{l}\text { Conflict } \\
\# 2\end{array}$ & Jesus & $\begin{array}{l}\text { Address } \\
\text { Statements of } \\
\text { disapproval }\end{array}$ & $\begin{array}{l}\text { O faithless and depraved generation } \\
\text { How long shall I be with you and endure you? }\end{array}$ & $\begin{array}{l}\text { Jesus responds negatively, seemingly in } \\
\text { response to disciples' inability to complete } \\
\text { anterior healing request (cf. v. 20). Conflict } \\
\# 2 \text { is not resolved }\end{array}$ \\
\hline $2^{\prime}$ & $\begin{array}{l}\text { Healing } \\
\text { response: } \\
\text { Conflict \#1 } \\
\text { resolved }\end{array}$ & Jesus & $\begin{array}{l}\text { Statement of intent } \\
\text { Healing speech } \\
\text { Healing response } \\
\text { Time of healing }\end{array}$ & $\begin{array}{l}\text { Bring the boy to me here } \\
\text { Rebukes [demon] } \\
\text { Demon comes out } \\
\text { Boy healed from that hour }\end{array}$ & $\begin{array}{l}\text { Conflict \# } 1 \text { is resolved: Jesus completes the } \\
\text { healing exchange requested by father but } \\
\text { interrupted by disciples' inability }\end{array}$ \\
\hline
\end{tabular}

As in the two SOBA accounts we have already visited, we notice in the story of the Canaanite woman that the Matthean Jesus draws a boundary around the realm of his healing, a borderline that at least temporarily excludes some from direct access to his healing economy. From the point of view of exchange-based dynamics, there are two elements of note here. Firstly, in both of Jesus' statements, he construes himself and/or his powers as the substance, and hence the object, of exchange. In his first response, whether to the disciples, the woman, or both, he says that he was sent only to the lost sheep of the house of Israel. Here Jesus is not the sender; he is the one sent, the object of the sender. In his reply to the woman, Jesus draws an analogy between himself or his powers and the bread. He understands himself as the food, and he implies that if the food is given to the dogs, if his powers are shared with those outside the house of Israel, there will not be enough left for the children of Israel. Hence, to the extent that there is any insufficiency in Jesus' micro-economy, the source of this insufficiency resides within Jesus himself; it is as if he recognises that there is not enough of him to go around. This understanding holds a certain poignancy, signalling as it does the limits of Jesus' power, the constraints created by the fact of his being human. The second element of note from an exchange-based viewpoint has to do with the overarching exchange that occurs between Jesus and the woman. By her dogged determination and her worthy argumentation, the woman ends up besting Jesus, who is staged as her narrative opponent; in the end, she teaches the teacher, who, won over by her rhetorical prowess, lauds her faith and commands the healing she desires. On the one hand, then, the final exchange appears to occur when the daughter's infirmity is exchanged for healing. However, there is a less explicit exchange upon which this final exchange is predicated, namely, the shift in Jesus' understanding about the presence and worthiness of 'outsiders' within the house of Israel. Through the woman, Jesus learns that there is room at, or at least near, the table for those who have faith in his ability to heal, whether they are traditionally understood as within or outside the house of Israel. Given Jesus' iterated opposition to helping the woman because of his perception of her as an outsider, we as readers recognise that, had Jesus not exchanged his narrower view of who is inside the house of Israel for the woman's broader view, the final narrative exchange of infirmity for wholeness would likely not have been accomplished.
One final observation deserves our attention here. Our exchange-based reading of the stories of the centurion and the Canaanite woman reveals several parallels between them: In both accounts, the Matthean Jesus functions as the source of the conflict exchange and hence as the primary impediment to each SOBA's quest for healing. In each case, the SOBA engages Jesus verbally, and this speech serves to change Jesus' mind. Further, Jesus then recognises each SOBA as having not only faith, but great faith. Despite these and other similarities between the two accounts, however, there is one significant exchange-based difference between them, a variation that bears upon the recurring theme of Jesus' exclusion. In the story of the centurion, Jesus grapples with the question of what happens to insiders and outsiders. He concludes that many, but not all, outsiders will become insiders at the table of the great patriarchs, while those already reclining at the table will not only be moved away from the table but cast entirely out of the household into a place of darkness, tears and gnashing teeth. In the story of the Canaanite woman, Jesus again wrestles with the question of what happens to outsiders. This time, the table is expanded, and he accepts the outsider's presence without any corresponding expulsion of someone already at the table. Dare we hope that Jesus' economy has become, like the woman's, both inclusive and sufficient for all?

\section{(In)complete economies: The story of the man with an epileptic son (Mt 17:14-18)}

${ }^{14}$ When they came to the crowd, a man came to [Jesus] and knelt before him ${ }^{15}$ and said, "Lord, have mercy on my son, because he is epileptic and suffers terribly. He often falls into the fire and often into the water. ${ }^{16} \mathrm{I}$ brought him to your disciples, but they were not able to heal him." ${ }^{17}$ And Jesus answered, "O faithless and depraved generation! How long shall I be with you? How long shall I endure you? Bring him to me here." ${ }^{18}$ And Jesus rebuked it, and the demon came out from him, and the child was healed from that hour.

(Mt 17:14-18)

Our final SOBA account, namely that of the man with an epileptic son, tells of an interrupted economy later brought to completion (see Table 5). The story begins with a locational exchange wherein Jesus, along with the disciples, leaves behind the mountain of the transfiguration and the man emerges from 
the gathered crowd to kneel before him. The man initiates the healing exchange with the titular address of 'Lord' and, like the Canaanite woman, begins his healing request with a plea for mercy. Whereas the woman pleaded for mercy for herself, the man asks Jesus to have mercy on his son (17:15). The man goes on to give a detailed explanation of the son's malady and suffering: he is epileptic and suffers terribly due to his tendency to often fall into water and fire (v. 15).

The man then recounts an anterior healing request, one that he had made of the disciples some time earlier: 'I brought him to your disciples, but they were not able to heal him' (v. 16). This verse provides us with a background story, a unique feature among the four SOBA accounts; the verse lets us know that when the man comes to Jesus, he is not beginning his quest for healing but rather continuing it. He has not accepted the aborted healing transaction brought about by the disciples' inability but kneels before Jesus in an attempt to find a cure for his son. Also unique to this narrative, and revealed through the background story, is the attempt of the disciples to try their hand at healing, though, alas, they fail miserably. Thus, the background story serves to introduce the original conflict exchange. Given our understanding of the conflict exchange as initiated by whoever or whatever derails the healing process, the background story reveals that the disciples, despite their willingness to heal the boy, are the source of this account's conflict. Their inability to heal prevents the desired cure from being achieved, at least at first.

Following the man's healing request to Jesus and his recounting of the anterior request made to the disciples, Jesus speaks at last. Interestingly, his first words are not directed to the man in his distress. Of all the SOBAs, this man has the unique distinction of receiving from Jesus no word or action directed towards him in response to his healing plea; indeed, after verse 16 , the man seems to disappear entirely from the text. ${ }^{13}$ Rather than addressing the man and his renewed healing request, Jesus' first words, vocative and provocative, appear directed towards his disciples, and perhaps others in the crowd as well: 'O faithless and depraved generation! How long shall I be with you? How long shall I endure you?' (17:17). Thus, Jesus first engages not the man and his plea but rather the disciples and their failure. Jesus can be understood, then, as responding to the conflict exchange initiated by the disciples' failure; however, inasmuch as Jesus himself does not respond immediately to the man's renewed request for healing but delays the healing yet again, his response can be understood as initiating a second conflict exchange, albeit one nested within and depending on the conflict begun by the disciples.

Following Jesus' negative assessment of the disciples' earlier attempt to heal the boy, he then issues his statement of intent to heal, 'bring him to me here' (17:17). This imperative, in the second person plural, seems directed not to the boy's father but rather to the disciples. Further, the command signals that the boy, heretofore invisible upon the narrative stage, is somewhere nearby. This is the only SOBA account where the one for whom the healing is requested is present with the supplicant. Assumedly, the boy is brought to Jesus, who then effects his healing by rebuking the demon. ${ }^{14}$ The account ends with a narrative statement confirming the demon's departure from the child and the immediacy of the healing, 'from that hour' (17:18).

Turning to a consideration of the microstructure of this story, we observe an economy based on a shift from incomplete to completed transactions. This is the only one of the four SOBA accounts where a healing encounter begins prior to the locational exchange - here, when the man makes an earlier

13. The disappearing SOBA is not unique. In Mt $9: 23$, following the mention of 'the ruler's house', the leader too, disappears from the text as the focus shifts to the conflict with the mourners and then to the miracle healing itself.

14.Although the dative can understand either the boy or the demon as the object of Jesus' rebuke, I employ the more common translation here. healing request of the disciples. As the background story unfolds through the man's words to Jesus, it becomes clear that the man is unwilling to accept the failed healing exchange brought about by the disciples' inability. Instead, the father endeavours to complete the healing transaction by seeking out Jesus. When at last Jesus heals the boy, his actions serve to demonstrate that derailed exchanges can be put back on track, that incomplete transactions can yet be brought to fulfillment.

While the dominant microeconomy of this account is one of completion wrought from failure, we note that in this story, as in the other three Matthean SOBA accounts, this local economy depends in part upon Jesus excluding someone, in this case, his hapless disciples. For though the man's healing request is ultimately brought to fulfillment, the completion of the healing exchange does not occur until after Jesus has roundly and soundly berated his well-intentioned disciples for what he calls their faithlessness and depravity, until he has twice wondered aloud how much longer he will have to put up with them all. Jesus does not even begin to heal the boy until after he has named the disciples, and perhaps others in the crowd as well, as strangers to Jesus' understanding of faithfulness. Thus, the completeness of the healing exchange is achieved only after Jesus identifies what he perceives to be the incompleteness of the disciples and their faith.

Returning for a moment to the conflict cycle, we noted above that the initial conflict occurs offstage when the disciples prove unable to heal the boy; this first conflict is resolved when Jesus later heals the man's son. There is a second conflict in this story, one nested in the first, and this conflict begins when Jesus engages the disciples' failure before he completes the healing cycle. This second conflict is not resolved within the SOBA account proper but rather carries over into verses 19 and 20, to which we now briefly turn our attention.

In Matthew 17:19, 20, the disciples reprise the conflict exchange when they are alone with Jesus, asking him why they were unable to cast out the demon. Jesus blames their failure to heal the boy on their little faith. Their insufficient faith is the context for his saying about the mustard seed: 'If you have faith like a mustard seed, you will say to this mountain, "Move from there", and it will be moved and nothing will be impossible for you' $(17: 20)$. While Jesus' words address the second conflict, they leave open the question of whether or not the disciples will ever achieve such a faith. The use of the third class condition admits both the possibility that the disciples will eventually attain this kernel of faith and the possibility that they will not (Wallace 1996:696, 697). Jesus draws a future horizon, a moment when the disciples' faith may become sufficient to accomplish amazing deeds. Clearly, in the present narrative, the disciples have not reached this threshold of faith. The answer to whether or not they will, in the future, cross the line between insufficient and sufficient faith, lies somewhere beyond the limits of this SOBA story, indeed, beyond the end of the Gospel of Matthew itself (cf. Mt 28:17). As such, while the initial conflict concerning the boy's healing is resolved within the text, the conflict related to the disciples' inadequate faith remains unresolved even after the end of the narrative. ${ }^{15}$

As we reach the end of the four SOBA accounts, let us pause only momentarily to recall the conclusion of the Canaanite woman's story, where Jesus' limited and exclusive microeconomy of assumed insufficiency appeared to yield to a more inclusive and sufficient one. Here at the end of the father's story, we seem to have reverted to a more troubled, more ambivalent economy. Once again, we find Jesus naming a microeconomy of insufficiency, this time enacted by his disciples. As we leave behind the SOBA accounts, we are left yet again with the uneasy sense that, for Matthew's Jesus, fullness in one locale necessarily means lack of fullness elsewhere.

15. The disciples' inability to heal in this SOBA account is likely central to explaining the Matthean author's shifting understanding of the disciples' overall role as it varies Matthean author's shifting understanding of the disciples' overall role as it varies
between their commissioning in Matthew 10:1-8, which focuses on proclamation between their commissioning in Matthew 10:1-8, which focuses on proclamation
and healing, and Matthew 28:18-20, which emphasises proclamation and, in place of healing, baptism 


\section{LOCAL CONCLUSIONS AND GLOBAL POSSIBILITIES}

In undertaking this work on the Matthean SOBA accounts, I sought to offer the beginnings of a critical reading strategy, one that might allow for a more complex engagement with biblical stories in general and with the character of Jesus in particular. By paying attention to the texts' economic exchanges, my hope was to start developing a method that might prove helpful in two locations: the classrooms where I teach and the church where I worship. In concluding this paper, then, I will review the method and consider some of the general and specific conclusions that can be drawn from this review of the four SOBA narratives. Following this, I will offer some thoughts about the potential implications of these conclusions for pedagogy and Christian formation within my particular contexts. Finally, I will end with a few tentative reflections on why this method and its pedagogical and formational implications may have a theological import beyond their immediate contexts.

\section{Methodological considerations: Narrative microeconomies}

The proposed reading strategy involved a close reading of the texts and the activation of narrative dynamics through the language of their exchanges and their microeconomic patterns. One of the chief advantages of any close-reading strategy is its ability to slow down the reader, thereby increasing the likelihood that the reader will notice the details of the literary terrain through which $\mathrm{s} / \mathrm{he}$ is passing. One of the benefits of using economic language to examine the micro-exchanges within these SOBA stories is that it interrupts our normal but often unrecognised expectations concerning divine economies and miraculous outcomes, thereby providing a reading method that seems both to challenge and complement, but certainly not supplant, more traditional readings of these texts.

The work of exploring the texts began with an 'offstage' analysis of the texts' exchange dynamics. By asking questions such as who gives what to whom and what they receive in return, I identified three types of exchange - locational, healing, and conflict - within the SOBA accounts. I read the locational exchange, which marks the beginning of most of the SOBA accounts, as a moment of textual parity, with Jesus and the supplicant each giving up one locale for another one, namely, the point of encounter. The healing exchange has several rather easily identified elements, such as the titular address, the statement of malady and the request for healing spoken by the supplicant, and the intention to heal enacted or spoken aloud by Jesus. Together with the conflict exchange, which it surrounds, the healing exchange represents the heart of the negotiation for healing, as the SOBA states what s/he desires and Jesus counters with what he is able or willing to give. Of the three types of exchange, the conflict exchange shows the greatest narrative variability and was thus the hardest to identify. While operationalising more precisely both the source of the conflict and the duration of the conflict exchange lent a bit more rigour to the analysis of the conflict exchange, I sense that a fair amount of methodological looseness remains. Although this is true of any method based on a classification scheme, it nonetheless holds that any future efforts to develop this method will likely be well served by an even more careful specification of the conflict sequence.

Despite the vexations of schematising the conflict exchange, our examination of the SOBA stories' conflict exchanges has revealed some interesting observations. Most obviously, conflict is part and parcel of each of these accounts; in no SOBA account is healing achieved without it. Given the limits of the present synchronic analysis, it would be unwise to speculate redactively about the diachronic implications of these conflicts; however, it seems clear that whatever diverse functions these stories may have served within the Matthean community, they were written to address conflict-laden situations. Further work to flesh out this method could profitably extend the microeconomic analysis to the Matthean community itself, focusing more redactively on the political economy of the community's social settings and theologies, as suggested by the narrative conflicts.

Perhaps the most striking observation emerging from the analysis of the conflict exchange is how often Jesus functions in these stories as the initiator of the conflict exchange. Given that the Matthean author frequently stages the religious leaders both as Jesus' opponents and as the source of narrative conflicts (e.g., Mt 9:2-8, 10-13, 32, 33), I found myself surprised to realise that not only do the religious leaders never appear in these stories as Jesus' opponents, but when the narrative conflict is introduced, it is Jesus himself who is frequently its source. In the story of the centurion, Jesus' rhetorical rebuff ('Shall I come and heal him?') serves as the inceptive moment of narrative delay in the centurion's supplication for healing. In the account of the ruler, Jesus initiates the conflict with his contrary-to-narrative statement that the girl is merely asleep. His initial silence marks the start of the conflict exchange in the story of the Canaanite woman, while his subsequent verbal rejections prolong it. Finally, in the account of the man with an epileptic son, the primary conflict begins prior to the story with the disciples' failure to heal the boy. Jesus, however, delays the healing further by initiating a second conflict nested within the first as he berates the disciples for their failure. Not only, then does Jesus participate in each SOBA account's conflict exchange, but in all save the last story, Jesus initiates the conflict. Jesus, the source of healing, is equally staged as the source of delay, as the narrative impediment to restoration. According to the Matthean author, the hand that eventually heals is first the hand that hinders.

Moving beyond the conflict exchange, we now turn to a brief consideration of the microeconomies undergirding each of our SOBA narratives. One observation that emerged from our analysis of the individual texts is how varied the sub-structural economies are in their details. Though the broad economy of each text is one of miraculous exchange, the microeconomies of each story develop differently around exchanges of command and compliance, insider and outsider, sufficiency and insufficiency, life and death, and fullness and incompletion. Again, as is the case with all classification schemes, these local economies could be named in any number of ways; regardless of the chosen descriptor, however, the rich and varied details that constitute the internal microdynamics of each story would not be obscured.

One conclusion that can be drawn from an analysis of the texts microeconomies is that both the SOBA and Jesus contribute to the creation of these local economies; it is as if the stories' microeconomic dynamics are a collaborative phenomenon emerging from the narrative interaction of the SOBAs' and Jesus' words and actions. Thus, in the story of the centurion, the centurion voices a command microeconomy that sees his own power as analogically similar to but qualitatively inferior to Jesus' power. Jesus approves the centurion's microeconomic assessment and to it adds his own microeconomy of subversion and exclusion. In the story of the leader whose daughter died, it is the ruler who unhesitatingly names the transgressive, death-for-life microeconomy; however, it is Jesus who enacts the ruler's transgressive expectations by healing the daughter, thereby validating the ruler's local economy. In the account of the Canaanite woman, Jesus suggests a household-based economy where there is not enough to share with those outside the house of Israel. For her part, the woman walks Jesus into the triclinium of his household economy, as it were, where she points out that the ostensible outsiders are already inside the house, are already gathered around the table and, furthermore, there is enough for all to have something to eat. The story of the father with the epileptic son presents a shifting local economy, one that moves from incompletion to fulfillment. The father, 
by relating his earlier encounter with the disciples, introduces the idea of a healing economy that remains incomplete; Jesus brings this interrupted economy to fulfillment by healing the son. Before accomplishing this exchange, however, Jesus himself introduces a second local economy of incompletion by means of the one-two punch of his scathing rhetoric: he equates the disciples' inability to heal with faithlessness and depravity, an economy that remains unfulfilled and unresolved in this narrative and beyond. The microeconomies of the SOBA accounts, then, depend on the narrative negotiation that develops between Jesus and each story's characters. No one character - not even Jesus - single-handedly determines the local narrative economy in any of our SOBA stories.

The complexity and diversity that we observe in the construction of each SOBA account's microeconomy is equally apparent when we turn our attention to Jesus. Indeed, one of the most striking conclusions to be drawn from the present work is the recognition of how complexly and ambivalently the character of Jesus is portrayed across the sweep of these four Matthean stories. Yes, Jesus effects a healing at the end of each account. However, this constancy of outcome ought not to obscure the complexity of Jesus' development within each story. We noted earlier the consistent role Jesus plays in initiating at least one conflict exchange in each SOBA narrative. To this, we add the observation that in every SOBA account, Jesus excludes someone from his microeconomy, even if only temporarily. In the beginning of the story of the centurion, the centurion is rebuffed, while at the end, the sons [and daughters] of the kingdom are expelled. The story of the leader finds the disbelieving mourners and musicians put out of the house. The Canaanite woman is initially named as someone outside the house of Israel and thereby is excluded from Jesus' healing economy. At the end of this story, the woman is included without a corresponding exclusion, and we have reason to hope that Jesus' tendency to exclude has been textually subdued. This hope is dashed in the story of the man, where the completeness of Jesus' healing comes at the expense of the disciples and the named incompleteness of their faith. In this case, those closest to Jesus, while apparently not at risk of expulsion from his inner circle, are nonetheless identified as decidedly outside the healing economy. This last story, then, shows that the Matthean Jesus continues to exclude and that those closest to him are not immune to his exclusion.

We see, then, that both conflict and exclusion are consistent parts of the story arc in the SOBA narratives. Let us refine this general observation a little further: In each of the SOBA stories, at least part of the conflict exchange is developed around inclusion and exclusion. Even more, in each of these four stories, the exclusion versus inclusion conflict begins before the healing takes place. Thus, the narrative dynamics of each story stage the macroeconomy of healing as dependent on a microeconomy of exclusion-based conflict. As these stories are crafted, there is no healing without exclusion, even if the latter proves only temporary. From an exchange perspective, then, there is a narrative cost for healing, one paid not in species but in name: Before Jesus effects a healing, he will first identify, through words or actions, someone or some group as outside his circle of inclusion, acceptability, or ministry.

Jesus' propensity for exclusion does not occur haphazardly within these texts; rather, the Matthean author often links exclusion and inclusion to faith, and so we now consider briefly how faith interacts with exclusion in these stories. In three of the four SOBA narratives, whether one is included or excluded by Jesus depends on how one's faith is judged by Jesus. The centurion believes from the start that Jesus can heal his servant, but the centurion's plea for healing initially secures nothing but a rebuff from Jesus. However, when the centurion proclaims his faith that Jesus can heal at a distance by means of a word because of his power, he is adjudged by Jesus to have a great faith unlike anything Jesus has yet seen in Israel. The case of the mourners is more ambiguous. They clearly do not believe Jesus when he tells them the girl is only sleeping, but the text does not identify this as a matter of faithlessness. In the story of the Canaanite woman, Jesus eventually names the woman's faith as 'great'. As in the case of the centurion, it is not her initial belief that Jesus can heal that results in Jesus' favorable pronouncement. Rather, it is the woman's persistent belief that she is already a legitimate member of the house of Israel that seems to earn her Jesus' approval and her daughter's healing. Finally, in the story of the man with the epileptic son, the disciples' failure to heal is explicitly connected with the insufficiency of their faith. For the Matthean writer, then, it appears that faith, healing, and inclusion/exclusion have a dynamic and complex interaction. Further work is needed to specify this interaction and to define more fully how faith is operationalised within these stories.

We have spent time considering some of the complexities enacted by Jesus as they relate to conflict and exclusion. Let us now take into account some of the other attributes displayed by Jesus in these narratives. As is readily apparent, Matthew's Jesus can be highly adaptive and responsive; he does not speak or act in cookie-cutter fashion within these narratives, but rather responds with variability to each situation. He assumes or shares the transgressive economy of the ruler; without a word of protest - indeed, with almost no speech at all throughout the story - Jesus gets up and follows him to the place where he is needed. Jesus is swayed and convinced by both the centurion's and the Canaanite woman's arguments; he gains a new perspective about outsiders by listening to their voices and learning from them. He is not stopped by the failure of his disciples to effect a healing for the epileptic boy but takes action to bring the healing to completion. And if, on the one hand, Jesus does not resolve his habit of excluding one person or group before healing another, on the other hand, his character resists this binary and blurs it into an oddly flawed but nonetheless productive capacity as Jesus 'tries and tries again' throughout the trajectory of these stories. After all, the macroeconomy of the SOBA stories, notwithstanding Jesus' tendency to exclude and delay, is consistently one of healing.

In light of these several observations, I suggest that the one overarching conclusion that can be drawn from our readings of the Matthean SOBA accounts is that there is a pronounced disjuncture between the macro-narrative of the healing stories, whose outcome is always a miraculous exchange of infirmity for wholeness, and the microeconomics that form the stuff and substance of each SOBA story. Thus, if we attend only to the outcome of each account, we will miss a critical observation derived from our sub-structural analyses: The internal economies of these healing stories are not perfectly healthy. Instead, they are complex, multi-layered and ambivalent, as is the Jesus who participates in creating these narratives' microeconomies. As such, whatever other roles these healing stories may play, I suggest that they may profitably be read by modern Christians as cautionary tales that demand a nuanced reading. The Matthean SOBA accounts are not stories of unadulterated 'good news'. In fact, there are moments when they seem downright problematic and unethical. But alongside these troublesome moments, there is engagement, growth, change and healing, which textual shifts we have a better chance of apprehending if we allow ourselves to read Jesus as he is portrayed: as a dynamic, undetermined and complex character.

Recognising and respecting the complexities evident in both the character of Jesus and the microeconomies of these stories has significant implications for us in our role as consumers of biblical texts. Our close reading of the SOBA narratives indicates that these complexities are intimately connected to the healing outcome of each story: The miracle outcome emerges from the multiple and interconnecting complexities of the narrative and microeconomic exchanges, including those involving the developing character of Jesus. Stated more bluntly, the outcome of the healing exchange depends on the 
many textual complexities of the SOBA accounts. If we disallow the complexities of Jesus, if we exclude the possibility that his actions and words are something other than wholly good or perfectly loving or radically inclusive, then we not only fail to recognise the literary face of Jesus, but we ourselves, by severing the textual linkages between narrative complexity and miracle outcome, become the very ones who derail the story's healing exchange.

\section{Pedagogical and formational implications}

The contexts prompting this work on narrative microeconomies (as mentioned earlier) are the classrooms and the church rooms where I teach biblical exegesis and adult Christian formation, respectively. All of these rooms tend to be filled with Christians, most of whom self-identify as progressive and inclusive and many of whom base their understanding of progressive, inclusive Christianity on the person and ministry of the New Testament Jesus. Many of the progressive Christians within these locales understand inclusion as perfectly demonstrated by the Jesus of the gospels. Indeed, there is a general acceptance that whatever being a Christian might mean, the best example of any desired quality will be found in Jesus, who radically, completely and perfectly embodies it within the gospels passages. It is this assumption of the textual perfection of Jesus, I believe, that goes a long way towards explaining the widespread resistance to reading the biblical Jesus critically that I often encounter in both classroom and church room.

The first section of the conclusion offers, I hope, numerous textual examples that might problematise this understanding of 'nice Jesus', at least as he is portrayed in the Matthean SOBA narratives: Jesus tends to exclude or include a character depending on his, Jesus', assessment of that person's faith. Rather than 'radically inclusive', Jesus is seen to exclude by ignoring those who are outsiders. Jesus instigates conflicts, conflicts that delay the healing of people who are suffering terribly. He speaks harshly to those who are his closest companions. In terms of reading the Bible attentively, I think these observations have important formational and pedagogical implications about how we choose to teach, to read and to interpret the biblical Jesus: To acknowledge ambiguous narratives and an ambivalent Jesus is to relinquish a predetermined reading strategy and to engage more fully the texts and their many complexities. From a pedagogical perspective, the simple recognition that 'nice Jesus' is not an adequate description of the texts' dynamics is a profoundly important act.

Still, there are many reasons why allowing room for Jesus as other than 'radically good' or 'radically inclusive' is not an acceptable stopping point in the present endeavour. The one I will focus on here stems from my own ethical understanding that destruction for the sake of destruction is, generally speaking, not a worthy goal. If, as an instructor, I challenge students to relinquish their perception of Jesus as an unproblematic 'good guy', I had better offer them the tools to construct a different viewpoint so that they might be stretched in their faith, yes, but equally sustained. The most important formational question, then, is not whether the present method allows us to dissect Jesus and read him critically; in this regard, the method is certainly functional. Rather, the more significant question is whether the narrative microeconomic method, which effectively reveals a complex and ambivalent Jesus, has the wherewithal to offer us a biblical model of Christian engagement.

I believe it does.

Although the precise shape of this model will need to be further delineated, we consider here a few characteristics of the SOBA accounts' Jesus that might contribute to a reliable and robust model of progressive Christian engagement, grounded not in assumptions of Jesus' perfection but rather in textual evidence of his human actions and attitudes. We start with the element of conflict. Whether we assess his creating conflict positively or negatively, what is clear from the SOBA stories is that Jesus instigates conflict as he decides with whom he will and will not share his limited healing resources. Jesus is the one who both possesses the healing resources and the one who chooses whether or not to dispense them. And we see that he does not distribute his healing resources evenly. However, by the end of every SOBA account, every infirm person has been healed. What are we to make of this?

For one thing, we can conclude that Jesus is willing to change his mind. He is willing to be taught by the very people he initially deemed outside the realm of his healing ministry. The centurion and the Canaanite woman are pushed away by Jesus at the beginning of their encounter with him, but they persist in engaging him, and, in the end, they cause him to change his mind. They show him the narrowness of his thinking, and rather than defending his position, Jesus expands his vision. Jesus - the ultimate protagonist, the head of the disciples, the rabbi, the healer - this Jesus changes his mind. Surely there is some nugget for us Christians to glean from this observation?

Not only does this Jesus have a change of opinion, but he is convinced by those who are textually situated as most unlike him. The centurion is a representative of the Roman Empire, and most likely a Gentile. The woman is named by the narrator as a Canaanite, and by Jesus as a dog - an outsider, to say the least. And yet, Jesus listens to their voices. Although he thinks they are outside the realm of his healing mercy, he still listens to what they have to say. His opinion is not unmovable; his word (and his silence) is not the final word. He is willing to be taught by those who are geographically, politically and ethnically unlike him.

Still, Jesus does not always change his mind. The mourners are weeping for a girl they truly believe to be dead. The fact that they are mourning, and their presence as part of the community of grief, is what provokes Jesus to throw them out. Moreover, he does not invite them back in, not even to add their voices later to the good cause of celebration. They are put outside and they stay outside because they chose to join in the lamentation. Furthermore, let us not forget Jesus' own disciples, whom he calls faithless and depraved. These people who have left everything to follow Jesus (Mt 4:20, 22; 19:27) receive as recompensement an unmistakably negative tongue-lashing concerning the insufficiency of their faith - in front of a crowd no less. And Jesus does not retract these harsh words. Whether or not we perceive Jesus to be justified in his judgement of the disciples' faith, it is clear that he stands by his opinion. Here, he does not change his mind, which leaves us with a complex understanding of a Jesus who sometimes expands his point of view and sometimes does not, a Jesus who can embrace outsiders' opinions even as he upbraids those closest to him.

What other observations about Jesus might inform a model of progressive Christian thinking and action? One finding gleaned from the story of the ruler whose daughter died is that Jesus takes action even if the outcome seems determined, unchangeable and insurmountable. When faced with the seemingly impossible task of raising the dead, Jesus does not hesitate, but gets involved. He acts. True, he throws the mourners out of the house; he does not allow room for those who are addressing the problem from their perspective. Nonetheless, at least some of the time, he moves into places of suffering, and he tries to mediate the suffering.

Yet another insight provided by the story of the ruler comes with the quick mention that Jesus got up and followed him. Jesus apparently did not know where the leader lived. Rather than pretend he did, and rather than try to lead when he lacked the necessary directions, Jesus simply followed someone who knew the way. It seems a trivial detail: Jesus the leader allows himself to be led to the place where he is needed. Textually, there are moments to lead and moments to follow, and Jesus is presented as able to distinguish between them, at least some of the time. 
In looking at the structure of the SOBA accounts, we noticed a narrative characteristic evident in most of the stories: the locational exchange. Both Jesus and the SOBA change locations; they both show up at the place of encounter. Thus, the initial exchange tends to be an equal exchange. As the story progresses into the healing exchange, we noticed that the SOBA always speaks first. It is the SOBA, the person textually acquainted with the problems of the sufferer, who names the illness and defines the extent and nature of the suffering; neither the narrator nor Jesus provides this information. It is the SOBA, too, who asks Jesus directly or indirectly to heal the sufferer. Of course, Jesus does not always listen to or respond to the SOBA. In fact, of our four SOBAs, only the ruler receives an immediate indication of Jesus' intent to heal. While Jesus' response time may be deemed to need improvement, it is nonetheless evident that when Jesus does get around to healing, he is responding to the lived experience and knowledge shared by the SOBA. Jesus distributes his healing resources according to the needs voiced by each SOBA.

These are just a few of the insights that emerge from our narrative microeconomic analysis of the SOBA texts; numerous others could be added. What these insights suggest is that if, on the one hand, reckoning with the textual complexities of these stories produces an understanding of Jesus as less than perfect, on the other hand, a nuanced reading can equally yield a vision of Jesus as sincere, teachable, approachable, active, involved, undaunted by big problems, and willing to respond to others' assessments of situations about which he knows little. While there is much more that needs to be considered here if these early observations are to coalesce into a coherent, Jesus-based model of Christian engagement, the rough contours of such a model are, I hope, evident in the above paragraphs. What would be the formational implications of imitating a Jesus who did not always get it right but who kept on trying to listen and respond? What would be the pedagogical costs and benefits of allowing the details of a biblical text to challenge more actively our ideas about Jesus, whatever they may be? It is too early to know, but perhaps the SOBA narratives themselves provide a clue: Despite the messy, imperfect, distressing, and confusing encounters that can occur between Jesus, the SOBAs and other characters present in these stories, healing and wholeness are somehow achieved.

\section{Beyond these walls: Theological implications of local contexts}

Of the many questions that remain unanswered as we come to the end of this work, perhaps the most significant is: 'So what?' What does it matter if a few well-intentioned western Christians decide to fashion the narrative complexities of Jesus into a model for living out their Christian commitment? What difference does it make if a few western students learn yet one more way of exegeting biblical texts? What gospel imperative is achieved by proposing a method of operationalising gospel texts in terms of their narrative microeconomics? What possible impact can such a reading strategy have in the real world beyond the classroom, a world where any number of social ills daily plunder the lives of countless persons, a world where no overarching macroeconomy of healing and wholeness exists?

\section{I do not know.}

I do know, however, that the local can easily masquerade as the global. As a citizen of the United States of America, I see how the needs of my country, whether real or imagined, have shaped the way we move around the world, how we name the world, how we claim its natural and economic resources as our own, as vital to our national survival. This country's colonial history long ago yielded to an imperialistic expansion that continues today. Western imperialism does not have a straightforward, linear history, and it has always been contested, both from the inside and the outside. Nonetheless, imperialism has defined much of the western world's history, and the West's colonial hunger, which devoured lands near and far, has marked the global landscape.

Both the Church and the Academy - my spiritual and professional homes - have played significant roles in promulgating and maintaining the informal doctrines that justify western empire theologically and epistemologically. In particular, the western Church has not only shaped imperialism but it has been indelibly shaped by it as well. Because of this, our every re-enactment of Jesus through prayer, song, liturgy, Bible reading and even social action is inescapably grounded in our Church's ambivalent imperial history, both the good and the harmful. While the traditions of the western Church are deep and rich and meaningful, they are also steeped in the values of empire, with its posture of universal (i.e., western) Christian triumphalism.

Inescapable as the western Church's imperial history may be, most of the western Christians with whom I am currently in relationship have no wish to replicate a globalisation that holds the West, particularly the United States of America, as the centre of the universe. We deeply want to recognise our smallness, to name our local and broader contexts, to live responsibly and responsively within these contexts, and to develop sustainable relationships with other peoples who have their own deep and rich and meaningful and ambivalent faith traditions. But how do we interrupt the patterns of our history, how do we overcome the resistance instilled by western privilege and prerogative, and how do we learn to enact something different?

Among the many small steps being taken towards this end, I hope there might be space for a method of reading that actively grapples with the complexities of the biblical Jesus. Because an unproblematised Christ triumphing over the grave so seamlessly elided in western history into a highly problematic Christian triumphalism, with western Christians 'marching as to war' against spiritual foes and emerging markets all over the globe, ${ }^{16}$ it is incumbent upon those of us who desire more sustainable global theological economies not only to name this triumphalist macroeconomy but to counter it with an alternative model of exchange. Any model emerging out of a context of empire will inevitably replicate the very dynamics of imperialism it hopes to subvert. However, the fact that no such model can be 'pure' or 'perfect' (questionable outcomes to aim for in the first place) does not mean we in the West ought not to try to interrupt the voices of imperial power. But where shall we look to find the source of such a subversive replication?

The seeds of an alternative model may lie precisely within the Bible's microeconomies, where we encounter, at least in the present stories, not a pristine Christ but rather a not-so-perfect Jesus who, in response to requests for healing, nonetheless tries once, twice, thrice, and again. Perhaps by reading more attentively these narrative microexchanges we might come to see Jesus not so much as a supra-national, trans-historical phenomenon, but more as a person with his own geography, his own history, his own social contexts. By reading Jesus' textual embeddedness, we western Christians may be better able to recognise and live within our own limited boundaries, both individual and communal. Like the centurion, we may then be better able to draw the needed analogies between Jesus' circumstances and our own: If Jesus is textually delimited by his geography and location, how much more are we? If Jesus sometimes got it wrong, failed to listen and shut down the voices of the oppressed, how much more will we? If Jesus, despite getting it wrong from time to time, kept on trying to listen, to learn, to respond, how can we do otherwise? In short, if we can dare to let Jesus live into the fullness of his textual ambiguities, we might learn to better recognise the fullness which is to say the limitations - of his humanity, and hence our own. Rather than performing Christ triumphant around the

16.For more on the interconnections between western Christianity and western imperialism, see Dube 2000; Kwok, Compier \& Rieger 2007; Sugirtharajah 2001. 
world, we may learn to re-enact Jesus the ambivalent within our many contexts. Global pretensions may yield to more nuanced and localised theological economies, which, with time and in reciprocity with other localised economies, may perhaps, as in our SOBA stories, go on to produce broader macroeconomies of healing. And that sounds like a pretty good exchange to me.

\section{REFERENCES}

Arndt, W.F. \& Gingrich, F.W. (eds. \& transl.), 1952, A GreekEnglish lexicon of the New Testament and other early Christian literature, 4th edn., University of Chicago, Chicago.

Betz, H.D., 1978, 'The early Christian miracle story: Some observations on the form critical problem', Semeia 11, 69-81.

Blight, D. \& Shafto, T., 1984, Introduction to microeconomics, Pitman, London.

Derrida, J., 1992, Given time: I. Counterfeit money, transl. P. Kamuf, University of Chicago, Chicago.

Dube, M..W., 2000, Postcolonial feminist interpretation of the Bible, Chalice, St. Louis.

France, R.T., 2007, The new international commentary on the New Testament, in G. Fee (ed.), The Gospel of Matthew, Eerdmans, Grand Rapids.

Funk, R.W., 1978, 'Form of the New Testament healing miracle story', Semeia 12, 57-96.

Hagner, D.A., 1993, Matthew 1-13 (Word Biblical commentary, vol. 33A), Word Books, Dallas.

Held, H.J., 1963, 'Matthew as interpreter of the miracle stories', in G. Borkamm, G. Barth \& H.J. Held (eds.), Tradition and interpretation in Matthew, transl. P. Scott, pp. 165-299, Westminster, Philadelphia.

Jackson, M., 1996, MBA economics, Blackwell, Cambridge.
Kohler, H., 1992, Economics, D.C. Heath, Lexington.

Kwok, P-L., Compier, D.H. \& Rieger, J. (eds.), 2007, Empire and the Christian tradition: New readings of classical theologians, Fortress Press, Minneapolis.

Liddell, H.G. \& Scott, R., 1996, A Greek-English lexicon, 4th edn., Clarendon, Oxford.

Luz, U., 2001, Matthew 8-20: A commentary (Hermeneia), transl. J.E. Crouch, Fortress Press, Minneapolis.

Mai, L.H., 1964, Approaches to economics, Littlefield \& Adams, Paterson.

Makin, J.H., 1975, Macroeconomics, Dryden, Hinsdale.

Nolland, J., 2005, 'The new international Greek testament commentary', in I.H. Marshall \& D.A. Hagner (eds.), The Gospel of Matthew: A commentary on the Greek text, Eerdmans, Grand Rapids.

Reynolds, L.G., 1973, Macroeconomics: Analysis and policy, Richard D. Irwin, Homewood.

Reynolds, L.G., 1979, Microeconomics: Analysis and policy, 3rd edn., Richard D. Irwin, Homewood.

Smyth, H.W., 1984, Greek grammar, Harvard University Press, Cambridge.

Sugirtharajah, R.S., 2001, The Bible and the third world, Cambridge University Press, Cambridge.

Theissen, G., 1983, The miracle stories of the early Christian tradition, T \& T Clark, Edinburgh.

Wainwright, E., 1994, 'The Gospel of Matthew', in E. Schussler Fiorenza (ed.), Searching the scriptures, vol. 2, A feminist commentary, pp. 635-707, Crossroads, New York.

Wallace, D.B., 1996, Greek grammar beyond the basics: An exegetical syntax of the New Testament, Zondervan, Grand Rapids. 